\title{
Elucidating determinants of aerosol composition through particle-type-based receptor modeling
}

\author{
M. L. McGuire ${ }^{1,2}$, C.-H. Jeong ${ }^{1}$, J. G. Slowik ${ }^{1,3,{ }^{*}}$, R. Y.-W. Chang ${ }^{1,3}$, J. C. Corbin ${ }^{1,3}$, G. Lu ${ }^{2}$, C. Mihele ${ }^{2}$, \\ P. J. G. Rehbein ${ }^{1}$, D. M. L. Sills ${ }^{4}$, J. P. D. Abbatt ${ }^{1,3}$, J. R. Brook ${ }^{2}$, and G. J. Evans ${ }^{1}$ \\ ${ }^{1}$ Southern Ontario Centre for Atmospheric Aerosol Research, University of Toronto, 200 College St., Toronto, \\ Ontario, Canada \\ ${ }^{2}$ Air Quality and Research Division, Science and Technology Branch, Environment Canada, 4905 Dufferin St., Toronto, \\ Ontario, Canada \\ ${ }^{3}$ Department of Chemistry, University of Toronto, St. George St., Toronto, Ontario, Canada \\ ${ }^{4}$ Cloud Physics and Severe Weather Research Section, Environment Canada, Toronto, Ontario, Canada \\ * now at: Paul Scherrer Institut, Villigen, Switzerland
}

Received: 30 January 2011 - Published in Atmos. Chem. Phys. Discuss.: 24 March 2011

Revised: 28 June 2011 - Accepted: 21 July 2011 - Published: 10 August 2011

\begin{abstract}
An aerosol time-of-flight mass spectrometer (ATOFMS) was deployed at a semi-rural site in southern Ontario to characterize the size and chemical composition of individual particles. Particle-type-based receptor modelling of these data was used to investigate the determinants of aerosol chemical composition in this region. Individual particles were classified into particle-types and positive matrix factorization (PMF) was applied to their temporal trends to separate and cross-apportion particle-types to factors. The extent of chemical processing for each factor was assessed by evaluating the internal and external mixing state of the characteristic particle-types. The nine factors identified helped to elucidate the coupled interactions of these determinants. Nitrate-laden dust was found to be the dominant type of locally emitted particles measured by ATOFMS. Several factors associated with aerosol transported to the site from intermediate local-to-regional distances were identified: the Organic factor was associated with a combustion source to the north-west; the ECOC Day factor was characterized by nearby local-to-regional carbonaceous emissions transported from the south-west during the daytime; and the Fireworks factor consisted of pyrotechnic particles from the Detroit region following holiday fireworks displays. Regional aerosol from farther emissions sources was reflected through three factors: two Biomass Burning factors and a highly chemically processed Long Range Transport factor. The Biomass
\end{abstract}

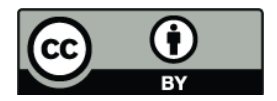

Correspondence to: G. J. Evans (greg.evans@utoronto.ca)
Burning factors were separated by PMF due to differences in chemical processing which were in part elucidated by the passage of two thunderstorm gust fronts with different air mass histories. The remaining two factors, ECOC Night and Nitrate Background, represented the night-time partitioning of nitrate to pre-existing particles of different origins. The distinct meteorological conditions observed during this month-long study in the summer of 2007 provided a unique range of temporal variability, enabling the elucidation of the determinants of aerosol chemical composition, including source emissions, chemical processing, and transport, at the Canada-US border. This paper presents the first study to elucidate the coupled influences of these determinants on temporal variability in aerosol chemical composition using single particle-type-based receptor modelling.

\section{Introduction}

Ambient particulate matter (PM) has been implicated in cardiopulmonary morbidity and decreased lung function (Dockery et al., 1993; Pope and Dockery, 2006; Nel, 2005; Brook et al., 2010), significant reduction in atmospheric visibility (Watson, 2002), and climate change (IPCC, 2007). Establishing direct links between these effects and emissions sources has proven challenging because of the wide array of source types and atmospheric processing mechanisms. Source apportionment techniques attempt to bridge this gap by assigning particles and/or particle components to specific sources and processes via mathematical analysis of ambient

Published by Copernicus Publications on behalf of the European Geosciences Union. 
data. Such models have proven to be useful tools for identifying emissions sources and characterizing them according to their temporal contributions and chemical profiles. Further, source apportionment models may assess the determinants of particulate matter composition and loading, namely source emissions, chemical processing, and atmospheric transport. Such information is crucial for policy-makers to identify and ultimately control source emissions.

Classes of source apportionment models include both chemical transport models (CTMs) and receptor models, discussed below. Chemical transport models, such as Environment Canada's AURAMS model (A Unified Regional Airquality Modelling System) (Gong et al., 2006; Makar et al., 2010), use emissions inventories that contain source profiles and emissions trends to determine the chemical processing and transport of emissions. However, their predictive power with respect to air quality modelling and climate scenario testing is limited by inaccuracies in the inventories, as well as by mechanistic parameters. Receptor models provide a complementary means of evaluating source characteristics and other determinants influencing air quality at a given location or receptor site. Receptor-only models such as the EPA's UNMIX (Lewis et al., 2003) and positive matrix factorization or PMF (Paatero and Tapper, 1994; Paatero, 1997), which interpret field measurements through factor analysis methods, have become popular because they do not require a-priori information on source profiles.

Traditionally, receptor modelling has been performed using long-term, low time-resolution data obtained from 24-h integrated filters. However, low time-resolution data does not allow the contributions of some factors affecting air quality to be investigated because the characteristic time of these features (e.g. fugitive emissions from local point sources, rapid changes in meteorology, photochemistry) is shorter than the time required to obtain a sufficient number of measurements (Wexler and Johnston, 2008). Thus higher time-resolution instrumentation is required to obtain a more accurate representation of all determinants affecting air quality at a given receptor site through receptor modelling.

Although many instruments are available to measure aerosol composition with high time-resolution, online massspectrometry techniques provide a breadth of chemical information in conjunction with high time-resolution that increases factor identification power. Chemical speciation information from the non-refractory component of $\mathrm{PM}_{1}$ ( $\mathrm{PM}<1.0 \mu \mathrm{m}$ in diameter) using the Aerodyne aerosol mass spectrometer (AMS) has been widely studied through the application of receptor modeling to the organic fraction of the aerosol (e.g. Zhang et al., 2005; Lanz et al., 2007; Aiken et al., 2009; Ulbrich et al., 2009). While this method has the capacity to differentiate between primary (e.g. hydrocarbonlike organic aerosol or HOA and biomass burning organic aerosol or BBOA) and secondary organic aerosol (e.g. oxygenated organic aerosol or OOA), it is limited in its ability to be source-specific. This is mainly due to a lack of source- specific information gathered by the AMS, such as individual organic compounds, and refractory species. This limitation can be overcome by utilizing instruments that provide such information, such as the thermal desorption aerosol gas chromatograph (TAG), which provides the molecular composition of organic aerosol (OA) (Williams et al., 2006). When PMF is applied to measurements from this instrument, it can provide more detailed apportionment of the primary and secondary organic aerosol source contributions (Williams et al., 2010). Single particle mass spectrometers (SPMS), such as the aerosol time-of-flight mass spectrometer (ATOFMS), also have the potential to overcome this limitation through the use of relatively high-powered lasers to desorb and ionize particles, thereby providing perhaps the most specific particle composition information (Noble et al., 1994; Gard et al., 1997). While most other instruments collect bulk aerosol samples, SPMS instruments provide chemical and physical information on single particles, thus allowing for the distinction between internally and externally mixed aerosol. Because these instruments measure a large number of particles during a typical field campaign, an effective strategy is required to reduce the dimensionality of these data for in-depth analysis. A popular method to achieve this result is the application of clustering techniques such as ART-2a (Carpenter et al., 1991; Song et al., 1999) and K-Means (MacQueen, 1967; Lloyd, 1982). These clustering methods assign particles to particle-types based on similarities between mass spectra. Interpretation of particle-types is useful for the determination of PM sources, as well as the chemical and physical processes that affect aerosol composition at a receptor site.

Multivariate receptor models can be applied to particletype data to further relate particle-types to PM sources and processes, though few studies have made such attempts. Owega et al. (2004) first applied PMF to ART-2a generated particle types from SPMS data produced by a laser ablation mass spectrometer (LAMS) (Owega et al., 2004). Nine factors were resolved from this analysis and each was identified as having a primary aerosol source having undergone some degree of chemical processing. PMF has also previously been applied to particle-types obtained by ART-2a clustering of ATOFMS data (Eatough et al., 2008). In the SOAR 2005 study, Eatough et al. (2008) found that the number of factors influencing PM composition increased from 6 to 16 with the addition of 19 particle-types to semi-continuous measures of PM composition (Eatough et al., 2008). Another study in Cork Harbour, Ireland, used a similar approach by combining comparable semi-continuous PM measurements with ATOFMS particle-types determined using the K-Mean clustering algorithm (Healy et al., 2010). The combined dataset yielded a 6 factor solution, with each factor again representing primary aerosol emissions having undergone some degree of chemical processing. 
This paper describes the application of PMF to ATOFMS data collected during the summer of 2007 in south-western Ontario, Canada, as part of the Border Air Quality and Meteorology Study (BAQS-Met). The overarching objective of BAQS-Met was to understand the determinants affecting air quality in this border region, particularly with respect to source emissions, chemical processing, and transport. Because this area experiences highly variable meteorology induced by the presence of the Great Lakes (e.g. lake breezes) (Sills et al., 2011), particular emphasis was placed on understanding how these determinants were influenced by complex meteorology.

Central to the particle-type PMF analysis presented in this paper is the expectation that there is not necessarily a unique one-to-one correspondence between a particle-type and a source. The implications of this are that: (a) a given source or process may be characterized by a variety of different particle-types, as has been shown in several previous single particle source characterization studies (Silva and Prather, 1997, 2000; Silva et al., 1999; Spencer et al., 2006; Drewnick et al., 2008) and (b) a given particle-type may originate from different sources (thus resulting in the apportionment of one particle-type to different factors). Thus PMF was used to investigate the external mixture of particletypes describing a given factor, as well as the internal mixing state of those characteristic particle-types. It was hypothesized that this cross-apportionment of particle-types based on their temporal covariance would allow the relative roles of the determinants affecting aerosol composition to be resolved. This paper presents the first study to elucidate the coupled influences of these determinants on temporal variability in aerosol chemical composition using single particletype-based receptor modelling.

\section{Methods}

\subsection{Sampling site and measurements}

During the BAQS-Met campaign (20 June-10 July 2007), three supersites were set up to obtain high time-resolution measurements of particle chemical speciation and size as well as trace gases. The supersite of interest for this work is Harrow, Ontario $\left(42^{\circ} 1^{\prime} 58.95^{\prime \prime} \mathrm{N}, 82^{\circ} 53^{\prime} 35.61^{\prime \prime} \mathrm{W}\right)$, which was located $5 \mathrm{~km}$ north of Lake Erie at a semi-rural Agriculture Canada facility (Fig. 1). In addition to expected emissions arising from agricultural activity from within the region, Harrow was influenced by many PM sources and precursor gases whose geographic origins could be categorized by three spatial scales: local, local-to-regional, and regional. Local emissions were expected from sources within and near Harrow, namely agricultural practices and light traffic. Local-to-regional scale emissions were expected from nearby urban centres such as the Windsor/Detroit metropolitan area, Toledo and Cleveland, as well as numerous coal- fired power plants around Lake Erie. Regional emissions were mostly expected from coal-fired power plants along the US Ohio River valley as well as more distant cities. Aerosol measurements were made aboard MAPLE (Mobile Analysis of Particulate in the Environment), a mobile laboratory operated by the Southern Ontario Centre for Atmospheric Aerosol Research. Ambient air was sampled through a $2.5 \mathrm{~cm}$ inner diameter stainless steel inlet at approximately $301 \mathrm{~min}^{-1}$ through a $\mathrm{PM}_{2.5}$ cyclone (URG, Chapel Hill, NC, USA), and was subsequently transferred to several instruments located along a $2.5 \mathrm{~cm}$ inner diameter, $5 \mathrm{~m}$ long stainless steel sampling line. Measurements of $\mathrm{PM}_{2.5}$ mass concentration were made at one minute intervals using a TSI DustTrak (TSI, Inc., Shoreview, MN, USA). Elemental and organic carbon mass concentrations were measured simultaneously and reported at two hour time intervals using a thermal/optical semi-continuous organic carbon and elemental carbon analyzer (Sunset OCEC analyzer) (Sunset Laboratory, Tigard, OR, USA). An Aerodyne Time-of-Flight Aerosol Mass Spectrometer (c-ToF-AMS) (Aerodyne, Billerica, MA, USA) was used to characterize the non-refractory aerosol fraction, and a TSI 3800-100 Aerosol Time-of-Flight Mass Spectrometer (ATOFMS) (TSI, Inc., Shoreview, MN, USA) was used to characterize both the non-refractory and refractory aerosol fractions. Results from the c-ToF-AMS have been reported in another publication (Slowik et al., 2011).

This publication focuses on receptor modeling results obtained by ATOFMS, which has been described in detail elsewhere (Prather et al., 1994; Gard et al., 1997). In brief, ambient air is sampled at $0.11 \mathrm{~min}^{-1}$, from which the aerosol is focused into a tightly collimated beam and accelerated through an aerodynamic focusing lens (AFL). Particles emerge from the aerodynamic lens at their terminal velocities, and pass through two $532 \mathrm{~nm}$ diode-pumped solid-state lasers used to measure their vacuum aerodynamic diameter $\left(D_{\text {va }}\right)$. A high-powered pulsed Nd:YAG $(266 \mathrm{~nm})$ desorption/ionization laser is then fired at each particle once it enters the mass spectrometer region. Positive and negative ions produced from the laser desorption ionization are accelerated by an electromagnetic field through two opposing flight tubes towards micro-channel plate detectors, thereby producing both positive and negative ion mass spectra. The ATOFMS is known to experience size-dependent transmission losses, which can be accounted for by comparing particle counts to collocated instruments (Wenzel et al., 2003; Jeong et al., 2011a). However, ATOFMS mass spectra provide only semi-quantitative information on particle composition due to matrix effects during ionization (Reilly et al., 2000). The quantification of certain PM species and particletypes measured by ATOFMS during this study is described in another manuscript (Jeong et al., 2011a). The ATOFMS was operated from 19 June-11 July 2007, and measured particles in the approximate range of 0.1 to $3 \mu \mathrm{m}$ using the AFL100 aerodynamic focusing lens, except for a brief period from 


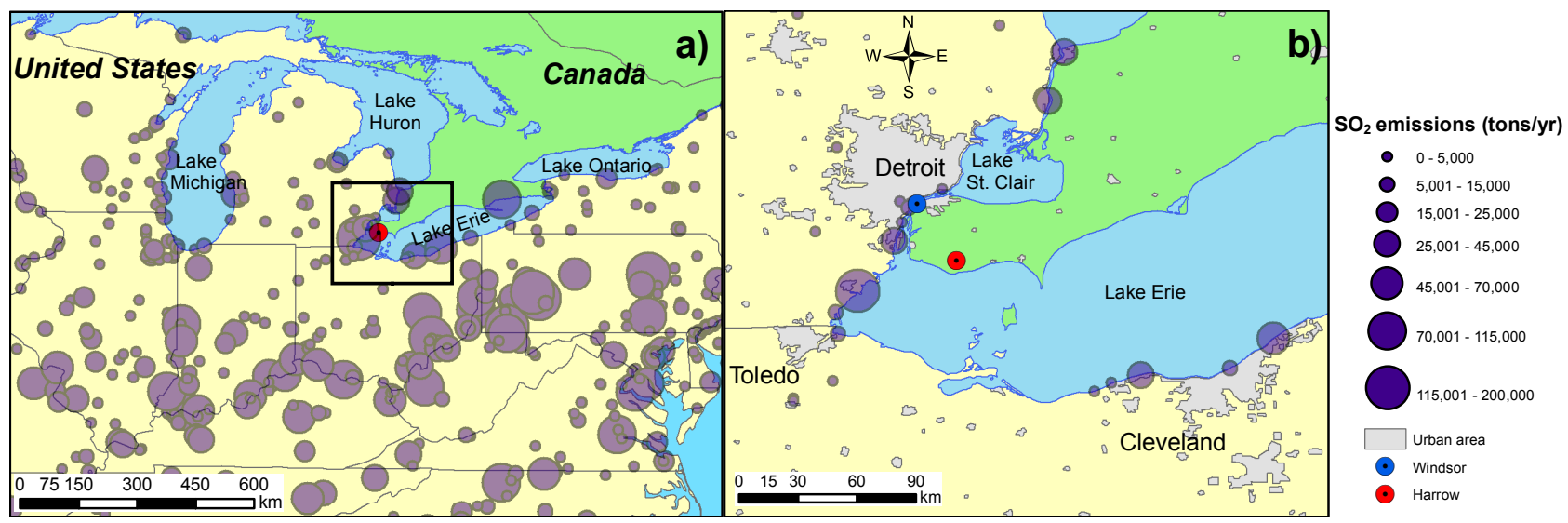

Fig. 1. Location of the receptor site, Harrow, Ontario within North America $\left(42^{\circ} 1^{\prime} 58.95^{\prime \prime} \mathrm{N}, 82^{\circ} 53^{\prime} 35.61^{\prime \prime} \mathrm{W}\right)$. The distribution of coal-fired power plants is illustrated by $\mathrm{SO}_{2}$ emissions in (a). Shown in (b) is the location of the receptor site within the BAQS-Met region relative to several large cities, including Windsor, Ontario, where the CRUISER mobile laboratory was stationed $\left(42^{\circ} 16^{\prime} 59.00^{\prime \prime} \mathrm{N}, 83^{\circ} 5^{\prime} 5.00^{\prime \prime} \mathrm{W}\right)$.

28-30 June 2007 when the ultrafine lens (AFL030) was used. Only ATOFMS measurements made with the AFL100 were used for this publication.

Measurements of other trace gases were made at Harrow using several TECO gas monitors (ThermoElectron Corporation, Hampton, $\mathrm{NH}, \mathrm{USA}$ ): $\mathrm{NO}_{\mathrm{x}}$ (TECO 42c), $\mathrm{O}_{3}$ (TECO 49i), $\mathrm{SO}_{2}$ (TECO 43i), and CO (TECO 48i). Meteorological parameters (i.e. wind direction, wind speed, temperature, and relative humidity) were assessed using an Orion weather station from Columbia Weather Systems installed on a telescopic tower on MAPLE at an elevation of approximately $10 \mathrm{~m}$ above ground level (a.g.l.) The spatial extent of aerosol composition in the BAQS-Met region was also evaluated by comparing measurements from Harrow with measurements from another BAQS-Met study site in Windsor, Ontario (40 km northeast of Harrow). The Windsor measurements of interest were made by a quadrupole Aerodyne AMS (Q-AMS) (Aerodyne Research, Inc., Billerica, MA, USA) which was housed by Environment Canada's CRUISER mobile laboratory, stationed at $42^{\circ} 16^{\prime} 59.00^{\prime \prime} \mathrm{N}, 83^{\circ} 5^{\prime} 5.00^{\prime \prime} \mathrm{W}$, near downtown Windsor.

\subsection{Positive Matrix Factorization}

Positive matrix factorization, or PMF (Paatero and Tapper, 1993, 1994; Paatero, 1997), is a bilinear factor analysis model that can be used to interpret aerosol chemical composition data. It is applied to an $n \times m$ matrix of data, $X$, by solving the general receptor equation:

$x_{i j}=\sum_{k=1}^{p} g_{i k} f_{k j}+e_{i j}$,

where $n$ is the number of samples and $m$ is the number of species; $x_{i j}$ is the $j^{\text {th }}$ species concentration measured in the $i^{\text {th }}$ sample; $g_{i k}$ is the concentration of the $k^{\text {th }}$ source that contributes to the $i^{\text {th }}$ sample; $f_{k j}$ is the $j^{\text {th }}$ species mass fraction that contributes to the $k^{\text {th }}$ source; $e_{i j}$ is the residual associated with the $j^{\text {th }}$ species concentration measured in the $i^{\text {th }}$ sample; and $p$ is the number of independent sources that are chosen by the user. The general receptor equation is solved iteratively using a least-squares algorithm by minimizing the parameter $Q$, defined as:

$Q=\sum_{i=1}^{n} \sum_{j=1}^{m}\left(e_{i j} / s_{i j}\right)^{2}$,

where $s_{i j}$ is an element in the $i \times j$ matrix, $\mathbf{S}$, of uncertainties used to weight each element in $X$ when solving the general receptor equation.

The number of factors used to represent the data, or the PMF solution, must be carefully chosen by the user. Foremost, the robustness of a solution is assessed by determining whether each factor is physically meaningful (Buset et al., 2006). This is further supported by evaluating several mathematical criteria: the quality of fit, the identification of a global minimum, and the uncertainties in the factor profiles and contributions. Quality of fit is determined by examining the ratio of the calculated $Q$ value by running PMF in the robust mode to the theoretical or expected $Q$ value $\left(Q_{\text {robust }} / Q_{\text {exp }}\right)$, where $Q_{\exp }=m n-p(m+n)$, and a good fit exists when $Q_{\text {robust }} / Q_{\exp } \sim 1$. The existence and identification of a global minimum can be supported by initiating the PMF algorithm from different random matrix starting points or seed values (Paatero, 2007); 100 seeds are recommended by the EPA PMF 3.0 Use's Manual (Norris et al., 2008). The uncertainty in each solution's factor profiles and contributions can be partially assessed through bootstrapping (Ulbrich et al., 2009). Once a reasonable solution has been identified, FPeak analysis, which involves controlled rotations of the $\mathbf{F}$ and $\mathbf{G}$ matrices, can be performed to investigate the rotational ambiguity of the solution, and to determine whether an improved solution can be identified by making 
such a rotation. In this study, PMF analysis was performed using the PMF2 algorithm, which along with all diagnostic checks, was executed using the custom software PMF Evaluation Tool (PET) (University of Colorado at Boulder, Boulder, CO) (Ulbrich et al., 2009) operated from within Igor Pro (version 6.1.2.1, WaveMatrics, Inc., Portland, OR, USA).

\subsection{Clustering ATOFMS single particle mass spectra}

A total of 183410 particles were sized by ATOFMS during BAQS-Met, of which 66920 particles were ionized (36\% hit efficiency). Figure S2 in the Supplement shows that the ionized particles were slightly bi-modally distributed, with a larger mode at $0.65 \mu \mathrm{m}$, and a smaller mode at $0.35 \mu \mathrm{m}$. The mass spectra of the ionized particles were peak listed using TSI's MS-Analyze software (TSI, Inc., Shoreview, MN, USA). A peak was identified if its height exceeded 20 arbitrary units (AU) above the mass spectral signal baseline, if its peak area was greater than 20 squared $\mathrm{AU}$, and if its fractional contribution to the total peak area was greater than 0.001. A database was created with this data using the custom MATLAB toolkit Yet Another ATOFMS Data Analyzer (YAADA v2.11, modified as described below), from which the ART-2a clustering algorithm was executed (Carpenter et al., 1991; Song et al., 1999). This clustering algorithm assigns particles to different clusters based on spectral similarity. Normalized particle mass spectra are compared to the average mass spectra of existing clusters by calculating the dot product between them. If the largest dot product with any pre-existing cluster is greater than a user-defined maximum (the vigilance factor), the particle of interest is assigned to that cluster; otherwise a new cluster is created. Hence, higher vigilance factors result in more clusters.

Prior to clustering, the mass spectral peak areas were logtransformed to allow for less intense, yet important peaks to inform the clustering (e.g. $m / z-195$, an indicator of sulphuric acid). As a consequence, lower than typical (e.g. 0.8) vigilance factors were explored, as typical ones resulted in too many clusters (herein referred to as particle-types) for interpretation and PMF analysis. For instance, using a vigilance factor of 0.8 produced 606 particle-types, which was not only far too many for interpretation, but each one also contained an insignificant number of particles for a robust PMF analysis (i.e. too few particles per hour). While manually recombining the particle-types based on their spectral, temporal, and particle size similarities is a common method for reducing their number, for this study this technique was avoided as it yielded PMF solutions without global minima. This was probably caused by the sensitivity of PMF towards small errors in the recombination process from subjective comparisons between particle-types: re-combining the timeseries of particle-types inherently changes the co-linearity between particle-types in the PMF matrix. It follows that inaccurately recombining particle-types directly affects the extent to which useful factors can be extracted using PMF.
Hence, errors in the subjective manual recombination process, which cannot be easily accounted for in the PMF error model, likely result in undue errors in the PMF analysis. A lower vigilance factor was ultimately chosen to ensure that an interpretable number of particle-types was obtained, and that enough of these contained a significant amount of signal for PMF analysis (specifically, that $>95 \%$ of particles were captured in particle-types with $>500$ particles). A vigilance factor of 0.3 satisfied this criterion by producing 46 particle-types, of which the top 33 were used for PMF analysis. Particle-types 34 through 46 each contained an insufficient number of particles per hour for analysis. For brevity, the particle-types are generally referred to herein using a name based on their abundance alone $(\mathrm{C} 1$ through $\mathrm{C} 33$, where $\mathrm{C} 1$ contained the most particles and $\mathrm{C} 33$ the fewest).

As the ATOFMS is known to experience size-dependent transmission biases (Allen et al., 2000; Wenzel et al., 2003), the possibility of correcting for these losses was investigated for the purpose of performing semi-quantitative particle apportionment using the enhanced scaling method presented by Jeong et al. (2011a). This scaling method corrects for the size-resolved transmission bias by scaling up ATOFMS particle number concentrations using independent, collocated APS and FMPS particle number size distributions, both of which were available during this campaign. The methods, results and discussion of this analysis are presented in Sect. 3 of the Supplement. In summary, particle number scaling to account for the transmission bias did not lead to robust PMF solutions. A 9 factor solution, which was chosen to compare with that chosen for the unscaled PMF analysis, was found to have higher residuals, a lower $R^{2}(0.92)$, and a global minimum was not produced from the 100 seed values that were tested (as judged from the $Q / Q_{\text {exp }}$ value). Furthermore, the factor profiles differed significantly from those from the unscaled analysis, without providing any new logical understanding of particle-type mixing.

This undesirable result was attributable to the large scaling factors required to scale up particles from the smallest size bin $\left(D_{\mathrm{va}}<0.52 \mu \mathrm{m}\right)$, which experienced the greatest transmission losses. Effectively, scaling caused the times series of each particle type to be dominated by the portion of that particle type within the smallest size bin. Given the lower efficiency of the ATOFMS for these small particles, these time series were often the noisiest. Comparing Figs. S2 and $\mathrm{S} 10$ it can be seen that particles with $D_{\text {va }}<0.52 \mu \mathrm{m}$ were scaled up by about 2 orders of magnitude more than larger particles. Thus, PMF analysis was essentially performed on scaled particle-type time series that were dominated by the convolution between a very large scaling factor and a noisy time trend from the smallest hit particles. More details and discussion on the PMF analysis of scaled particle-types can be found in the Supplement. In the end, as this method did not lead to robust PMF solutions, particles were left unscaled for PMF analysis, leading to a qualitative receptor modeling study. In summary, the unscaled PMF solution presented 
in the manuscript emphasizes the characteristics of particles in the size ranges efficiently detected by the ATOFMS, rather than those of $D_{\mathrm{va}}<0.52 \mu \mathrm{m}$ which were measured with lower efficiency.

\subsection{PMF analysis of ATOFMS particle-types}

The data matrix used in this study was constructed from the hourly summed time series of the ATOFMS particle-types, which resulted in 474 rows (hours) and 33 columns (particletypes). The error matrix (S) for PMF modelling is typically constructed by the user using the PMF default error model (Error Model $=-12$ ), which specifies that:

$s_{i j}=t_{i j}+\mathrm{C} 3\left|x_{i j}\right|$,

where the elements $\left(t_{i j}\right)$ of $T$ represent the analytical uncertainty of the measurement, and C3 is a coefficient used to downweight the influence of large and sporadic $x_{i j}$ values on the solution (Paatero, 2007). Several options for pre-treating the data and constructing the error matrices were explored, including those used in the few studies that have been published for similar data (Owega et al., 2004; Eatough et al., 2008; Healy et al., 2010). As analytical uncertainties and detection limits are not commonly reported with ATOFMS data, relying on only a $\mathrm{C} 3$ value to provide a constant percentage error of the data has been used in some studies (Eatough et al., 2008; Healy et al., 2010). Applying this error matrix construction using the previously used C3 of 0.15 (or $15 \%$ of the data matrix) revealed that these errors were too low, and not specific enough for these data, as it yielded solutions with very high residuals and low corresponding $R^{2}$ values (e.g. $Q_{\text {robust }} / Q_{\exp }=9.9$ and an $R^{2}$ of 0.93 for a nine factor solution). The method outlined by Owega et al. (2004) provided a better solution as it resulted in lower residuals and an improved quality of fit over the method outlined above (e.g. $Q_{\text {robust }} / Q_{\exp }=0.55$ and an $R^{2}$ of 0.96 , for a nine factor solution), and as such was used in this analysis.

To summarize the data and error matrix preparation process for the method of Owega et al. (2004), the time series of each particle-type was first smoothed to remove spurious noise by box-smoothing the 1-h summed particle counts using a 5-h averaging period. The error matrix, $\mathbf{S}$, was constructed using only the $\mathbf{T}$ matrix, which was calculated as the standard deviation of the hourly particle counts within the 5$\mathrm{h}$ period. A detection limit (DL) policy was also applied to account for observations with no particles. The DL for each particle-type was calculated as the fraction of hours with no measured particles divided by 5 given that one particle in the five hour averaging period was the lowest non-zero observation rate. The error associated with below DL observations was set to 5/6DL (Reff et al., 2007). Abrupt, yet sustained increases in the particle-type hourly counts (i.e. increases that were well beyond the data noise), were permitted to appropriately influence the PMF solution by applying an exponen- tial decay function to the error matrix for these observations (Owega et al., 2004). The decay function is given by:

$f\left(s_{i j}\right)=\exp \left(\frac{-s_{i j}}{b}\right)$,

where $s_{i j}$ is the error value and $b$ is the maximum observed hourly particle count for the given particle-type. Lastly, the signal to noise $(S / N)$ ratio of all particle-types was calculated to determine if downweighting of noisy particle-types was required (Paatero and Hopke, 2003). However, all particletypes introduced to the PMF model displayed $S / N>2$, and thus no down-weighting was applied. From this method, the average error applied to any particle-type was $50 \%$, with a range of 32 to $79 \%$ of the average of each variable.

Inclusion of other online measurements (e.g. $\mathrm{PM}_{2.5}$ mass, EC/OC, trace gases) has been a useful method in previous PMF of previous ATOFMS PMF studies towards improving source characterisation (Eatough et al., 2008; Healy et al., 2010). Given the potential benefits of including other online measurements, this practice was considered for this analysis. However, in order to ensure good cross-apportionment of the external online measurements and ATOFMS particle types, a good degree of correlation is required between them. Since most of the correlation coefficients $(85 \%)$ between the external online measurements and ATOFMS particle-type time series did not exceed a moderate level (Pearson $r=0.4$ ), their inclusion in the PMF analysis would result in the creation of new factors. Without moderate cross-apportionment to other factors, their inclusion could not be justified. As such, postPMF correlation analysis was deemed to be the best method for including other online variables in the analysis.

\subsection{Geographic origins}

The geographic origins of the PMF factors were explored using the conditional probability function (CPF), and the potential source contribution function (PSCF). The CPF utilizes wind direction measurements to identify wind sectors of high source probability relative to the receptor site (Ashbaugh et al., 1985; Kim et al., 2003), and is given by:

$\mathrm{CPF}=\frac{m_{\Delta \theta}}{n_{\Delta \theta}}$,

where $m_{\Delta \theta}$ is the number of occurrences from the wind sector $\Delta \theta\left(15^{\circ}\right.$ in this study) that exceed a given threshold (here the 50th percentile), which is then normalized to $n_{\Delta \theta}$, the total number of occurrences from that wind sector. Occurrences with wind speeds $<1 \mathrm{~m} \mathrm{~s}^{-1}$ were deleted, and CPF values for sectors with $\leq 5$ observations were downweighted by a factor of three to prevent over-interpretation of results from infrequently observed wind sectors.

The regional character of PMF factors is typically investigated by applying PSCF to air mass backtrajectories (Ashbaugh et al., 1985). The PSCF is given by:

$\mathrm{PSCF}=\frac{m_{i j}}{n_{i j}}$ 
where $m_{i j}$ is the number of times a factor contribution exceeds a predefined threshold (here the $50^{\text {th }}$ percentile) when traveling through geographic grid cell $i j$, and $n_{i j}$ is the number of times that an air mass is observed to have passed through cell $i j$.

Two different backtrajectory models were employed. The HYSPLIT model was used to investigate regional scale sources (Draxler, 1997; Draxler and Rolph, 2011; Rolph, 2010) using 48-h backtrajectories retrieved from the EDAS $40 \mathrm{~km}$ resolution meteorological dataset. The Canadian Meteorological Service of Canada's (CMC) high resolution trajectory model (D'Amours, 1998) was used for local-toregional scale emissions sources: using 24-h backtrajectories, the CMC model provided high temporal resolution, achieved by the two minute sequential increments in which each hourly backtrajectory was calculated. A high spatial resolution $(2.5 \mathrm{~km})$ was obtained by supplying a local area model (LAM) to the CMC model; the LAM contained high resolution meteorological data derived from the CMC's Global Environmental Multiscale (GEM) model (Cote et al., 1998). This trajectory analysis was limited to the local-toregional scale as it only covered an area of $39.5^{\circ}-46.6^{\circ}$ latitude (north) and $86.5^{\circ}-77.7^{\circ}$ longitude (west). All trajectories were calculated arriving at Harrow at $500 \mathrm{~m}$ above ground level.

\section{Results and discussion}

\subsection{ATOFMS particle-types}

Forty-six particle-types were identified using ART-2a. Examination of the chemical characteristics, temporal patterns, and size distributions of the 33 most populous of these indicated that they tended to fall into seven broad families of particle-types. These families were named based on their chemical composition or source class, and these names were used to help describe the PMF results. The families were: EC_OC (elemental carbon internally mixed with organic carbon, size modes from $0.67-0.69 \mu \mathrm{m}$ ), EC (elemental carbon, size modes of 0.32 and $0.76 \mu \mathrm{m}$ ), OC_S_N (organic carbon internally mixed with sulphate and nitrate, size modes from 0.51-0.69 $\mu \mathrm{m}$ ), OC (organic carbon, size modes from 0.56$0.75 \mu \mathrm{m}$ ), AMINE (amine-containing, size modes of 0.65 and $0.67 \mu \mathrm{m}$ ), FIREWORKS (size modes from $0.84-0.88 \mu \mathrm{m}$ ), and DUST (size modes from $0.64-1.42 \mu \mathrm{m}$ ). Table 1 summarizes their characteristic ions, and a brief account of their general composition is provided below. It can be seen from Table 1, as well as Figs. S3-S9 in the Supplement that some families exhibit a broader range in particle-type internal mixing states than others. A detailed description of the particletypes, as well as their mass spectra and size modes can be found in the Supplement.

\subsection{ATOFMS single particle-type families}

Figure S3 shows that the EC_OC family was characterized by elemental carbon internally mixed with organic carbon, which was likely oxidized. Each particle-type within this family displayed different relative amounts of sulphate, indicating that they were moderately to highly chemically processed. Two particle-types were attributed to the EC family (Fig. S4) based on their significant elemental carbon content: one particle-type appeared to be relatively fresh as it had the smallest size, while the other appeared more aged given its larger geometric mean particle diameter and significant sulphate content. The OC_S N family consisted of particletypes with significant organic carbon content, along with significant sulphate and/or nitrate, as shown in Fig. S5. Most of these appeared to be biomass burning particles with different chemical processing histories, except for one particle-type, C5, whose likely origins could not be determined. Particletypes grouped into the OC family (Fig. S6) contained significant organic carbon levels, including aromatics, and relatively little secondary inorganic material, indicating they had experienced less chemical processing than other OC rich particle-types, such as those in the OC_S_N family. Two particle-types were typified by a prominent amine peak at $m / z+59$, and as such were grouped into the AMINE family (Fig. S7). Their amine content was hypothesized to be the result of gaseous uptake during periods of high relative humidity onto pre-existing acidic particles (Rehbein et al., 2011). The FIREWORKS family (Fig. S8) was defined by several large-diameter particle-types containing ions, which suggested a pyrotechnic source. The final family was DUST (Fig. S9), whose particle-types were the largest in diameter among all those measured. All of these particle-types showed prominent peaks in the positive mass spectrum related to inorganic dust components; the lack of ammonium combined with elevated nitrate content suggested that the nitrate was neutralized by the inorganic cations. Particle-types were regrouped into factors through PMF analysis, with only some factors found to be similar to the particle-types families identified a-priori.

\subsection{Nine factor PMF solution}

PMF analysis of the 33 ATOFMS particle-types was performed for solutions ranging from 1 to 12 factors. A nine factor solution was chosen as it produced the most physically meaningful factors, and the highest quality result in terms of mathematical diagnostics. The following information informed the identification of the nine factors: (i) the allocation of particle-types to each factor to provide their overall chemical composition, (ii) the mean sizes of particle-types contained therein, and (iii) the factor's temporality and covariance with external measurements. The nine factors are summarized in Table 2, listed according to their particle number contribution. The temporal variability and apportionment of 
Table 1. Particle counts and major ions describing each particle-type and their corresponding families for the top 33 ATOFMS particle-types. The details of each of the C1-C33 particle-types are provided in the Supplement, including Figs. S3-S9.

\begin{tabular}{|c|c|c|c|c|c|}
\hline $\begin{array}{l}\text { Particle- } \\
\text { type } \\
\text { Family }\end{array}$ & $\begin{array}{l}\text { Particle } \\
\text { Counts }\end{array}$ & $\begin{array}{l}\text { Contri- } \\
\text { bution } \\
(\%)\end{array}$ & $\begin{array}{l}\text { Particle- } \\
\text { types }\end{array}$ & Positive Ion Mass Spectra & Negative Ion Mass Spectra \\
\hline \multirow[t]{2}{*}{ EC_OC } & \multirow[t]{2}{*}{14402} & \multirow[t]{2}{*}{21.7} & $\mathrm{C} 1, \mathrm{C} 4$ & $\begin{array}{l}{ }^{12 n} \mathrm{C}_{n(n=1-5)}^{+}{ }^{18} \mathrm{NH}_{4}^{+},{ }^{27} \mathrm{C}_{2} \mathrm{H}_{3}^{+}, \\
{ }^{43} \mathrm{C}_{3} \mathrm{H}_{7}^{+} /{ }^{43} \mathrm{C}_{2} \mathrm{H}_{3} \mathrm{O}^{+} /{ }^{43} \mathrm{CHNO}^{+}\end{array}$ & ${ }^{46} \mathrm{NO}_{2}^{-},{ }^{62} \mathrm{NO}_{3}^{-},{ }^{97} \mathrm{HSO}_{4}^{-}$ \\
\hline & & & $\mathrm{C} 3, \mathrm{C} 8$ & $\begin{array}{l}{ }^{12 n} \mathrm{C}_{n(n=1-5)}^{+},{ }^{27} \mathrm{C}_{2} \mathrm{H}_{3}^{+}, \\
{ }^{43} \mathrm{C}_{3} \mathrm{H}_{7}^{+} /{ }^{43} \mathrm{C}_{2} \mathrm{H}_{3} \mathrm{O}^{+} /{ }^{43} \mathrm{CHNO}^{+}\end{array}$ & - \\
\hline \multirow[t]{2}{*}{ EC } & \multirow[t]{2}{*}{4232} & \multirow[t]{2}{*}{6.4} & $\mathrm{C} 11$ & ${ }^{12 n} \mathrm{C}_{n(n=1-11)}^{+},{ }^{23} \mathrm{Na}^{+}$ & $\begin{array}{l}{ }^{12 n} \mathrm{C}_{n(n=1-8)}^{-},{ }^{16} \mathrm{O} /{ }^{17} \mathrm{OH}^{-}, \\
{ }^{26} \mathrm{CN}^{-},{ }^{46} \mathrm{NO}_{2}^{-}\end{array}$ \\
\hline & & & $\mathrm{C} 16$ & ${ }^{12 n} \mathrm{C}_{n}^{+},{ }^{39} \mathrm{~K}^{+}$ & $\begin{array}{l}{ }^{12 n} \mathrm{C}_{n(n=1-8)}^{-},{ }^{46} \mathrm{NO}_{2}^{-},{ }^{62} \mathrm{NO}_{3}^{-}, \\
{ }^{97} \mathrm{HSO}_{4}^{-}\end{array}$ \\
\hline \multirow[t]{2}{*}{ OC_S_N } & \multirow[t]{2}{*}{17639} & \multirow[t]{2}{*}{26.6} & $\mathrm{C} 2, \mathrm{C} 6, \mathrm{C} 7$ & $\begin{array}{l}{ }^{18} \mathrm{NH}_{4}^{+},{ }^{27} \mathrm{C}_{2} \mathrm{H}_{3}^{+},{ }^{39} \mathrm{~K}^{+} /{ }^{39} \mathrm{C}_{3} \mathrm{H}_{3}^{+}, \\
{ }^{43} \mathrm{C}_{3} \mathrm{H}_{7}^{+} /{ }^{43} \mathrm{C}_{2} \mathrm{H}_{3} \mathrm{O}^{+} /{ }^{43} \mathrm{CHNO}^{+}\end{array}$ & $\begin{array}{l}{ }^{26} \mathrm{CN}^{-},{ }^{42} \mathrm{CNO}^{-},{ }^{46} \mathrm{NO}_{2}^{-}, \\
{ }^{62} \mathrm{NO}_{3}^{-},{ }^{89}(\mathrm{COO})_{2} \mathrm{H}^{-},{ }^{97} \mathrm{HSO}_{4}^{-}, \\
{ }^{195} \mathrm{H}_{\left(\mathrm{HSO}_{4}\right)_{2}^{-}}\end{array}$ \\
\hline & & & $\begin{array}{l}\mathrm{C} 5, \mathrm{C} 10, \\
\mathrm{C} 14\end{array}$ & $\begin{array}{l}{ }^{18} \mathrm{NH}_{4}^{+},{ }^{27} \mathrm{C}_{2} \mathrm{H}_{3}^{+},{ }^{39} \mathrm{~K}^{+} /{ }^{39} \mathrm{C}_{3} \mathrm{H}_{3}^{+}, \\
{ }^{43} \mathrm{C}_{3} \mathrm{H}_{7}^{+} /{ }^{43} \mathrm{C}_{2} \mathrm{H}_{3} \mathrm{O}^{+} /{ }^{43} \mathrm{CHNO}^{+}\end{array}$ & $\begin{array}{l}{ }^{26} \mathrm{CN}^{-},{ }^{42} \mathrm{CNO}^{-},{ }^{46} \mathrm{NO}_{2}^{-}, \\
{ }^{62} \mathrm{NO}_{3}^{-},{ }^{89}(\mathrm{COO}){ }_{2} \mathrm{H}^{-},{ }^{97} \mathrm{HSO}_{4}^{-}\end{array}$ \\
\hline \multirow[t]{3}{*}{$\mathrm{OC}$} & \multirow[t]{3}{*}{7826} & \multirow[t]{3}{*}{11.8} & $\begin{array}{l}\text { C13, C15, } \\
\text { C18 }\end{array}$ & $\begin{array}{l}{ }^{18} \mathrm{NH}_{4}^{+},{ }^{27} \mathrm{C}_{2} \mathrm{H}_{3}^{+},{ }^{39} \mathrm{~K}^{+} /{ }^{39} \mathrm{C}_{3} \mathrm{H}_{3}^{+}, \\
{ }^{43} \mathrm{C}_{3} \mathrm{H}_{7}^{+},{ }^{43} \mathrm{C}_{2} \mathrm{H}_{3} \mathrm{O}^{+} /{ }^{43} \mathrm{CHNO}^{+} \\
{ }^{51} \mathrm{C}_{4} \mathrm{H}_{3}^{+},{ }^{63} \mathrm{C}_{5} \mathrm{H}_{3}^{+},{ }^{77} \mathrm{C}_{6} \mathrm{H}_{5}^{+}\end{array}$ & ${ }^{97} \mathrm{HSO}_{4}^{-}$ \\
\hline & & & $\mathrm{C} 27$ & $\begin{array}{l}{ }^{27} \mathrm{C}_{2} \mathrm{H}_{3}^{+},{ }^{39} \mathrm{~K}^{+} /{ }^{39} \mathrm{C}_{3} \mathrm{H}_{3}^{+}, \\
{ }^{43} \mathrm{C}_{3} \mathrm{H}_{7}^{+} /{ }^{43} \mathrm{C}_{2} \mathrm{H}_{3} \mathrm{O}^{+} /{ }^{43} \mathrm{CHNO}^{+}\end{array}$ & $\begin{array}{l}{ }^{26} \mathrm{CN}^{-},{ }^{42} \mathrm{CNO}^{-},{ }^{46} \mathrm{NO}_{2}^{-}, \\
{ }^{62} \mathrm{NO}_{3}^{-},{ }^{97} \mathrm{HSO}_{4}^{-}\end{array}$ \\
\hline & & & $\mathrm{C} 30$ & $\begin{array}{l}{ }^{27} \mathrm{C}_{2} \mathrm{H}_{3}^{+},{ }^{39} \mathrm{~K}^{+/}{ }^{39} \mathrm{C}_{3} \mathrm{H}_{3}^{+}, \\
{ }^{43} \mathrm{C}_{3} \mathrm{H}_{7}^{+} /{ }^{43} \mathrm{C}_{2} \mathrm{H}_{3} \mathrm{O}^{+} /{ }^{43} \mathrm{CHNO}^{+}\end{array}$ & ${ }^{26} \mathrm{CN}^{-},{ }^{46} \mathrm{NO}_{2}^{-}$ \\
\hline AMINE & 4274 & 6.5 & $\mathrm{C} 9, \mathrm{C} 20$ & $\begin{array}{l}{ }^{18} \mathrm{NH}_{4}^{+},{ }^{27} \mathrm{C}_{2} \mathrm{H}_{3}^{+},{ }^{39} \mathrm{~K}^{+} /{ }^{39} \mathrm{C}_{3} \mathrm{H}_{3}^{+}, \\
{ }^{43} \mathrm{C}_{3} \mathrm{H}_{7}^{+} /{ }^{43} \mathrm{C}_{2} \mathrm{H}_{3} \mathrm{O}^{+} /{ }^{43} \mathrm{CHNO}^{+} \\
{ }^{59} \mathrm{C}_{3} \mathrm{H}_{9} \mathrm{~N}^{+}\end{array}$ & $\begin{array}{l}{ }^{46} \mathrm{NO}_{2}^{-},{ }^{62} \mathrm{NO}_{3}^{-},{ }^{97} \mathrm{HSO}_{4}^{-}, \\
\left.{ }^{195} \mathrm{H}_{\left(\mathrm{HSO}_{4}\right)}\right)_{2}^{-}\end{array}$ \\
\hline \multirow[t]{2}{*}{$\begin{array}{l}\text { FIRE- } \\
\text { WORKS }\end{array}$} & \multirow[t]{2}{*}{6183} & \multirow[t]{2}{*}{9.4} & $\mathrm{C} 12, \mathrm{C} 23$ & $\begin{array}{l}{ }^{23} \mathrm{Na}^{+},{ }^{24} \mathrm{Mg}^{+},{ }^{39} \mathrm{~K}^{+}, \\
{ }^{155} \mathrm{BaOH}^{+},{ }^{140} \mathrm{Ba}^{+} / \\
\mathrm{K}_{2} \mathrm{NO}_{3}^{+}\end{array}$ & $\begin{array}{l}{ }^{16} \mathrm{O} /{ }^{17} \mathrm{OH}^{-},{ }^{35} \mathrm{Cl}^{-},{ }^{46} \mathrm{NO}_{2}^{-}, \\
{ }^{62} \mathrm{NO}_{3}^{-},{ }^{125} \mathrm{H}\left(\mathrm{NO}_{3}\right)_{2}^{-}, \\
{ }^{147} \mathrm{KNO}_{3} \mathrm{NO}_{2}^{-},{ }^{163} \mathrm{~K}_{\left(\mathrm{NO}_{3}\right)_{2}^{-},}\end{array}$ \\
\hline & & & $\mathrm{C} 19, \mathrm{C} 28$ & ${ }^{27} \mathrm{Al}^{+},{ }^{39} \mathrm{~K}^{+},{ }^{140} \mathrm{~K}_{2} \mathrm{NO}_{3}^{+}$ & ${ }^{46} \mathrm{NO}_{2}^{-},{ }^{62} \mathrm{NO}_{3}^{-},{ }^{125} \mathrm{H}\left(\mathrm{NO}_{3}\right)_{2}^{-}$ \\
\hline \multirow[t]{3}{*}{ DUST } & \multirow[t]{3}{*}{11668} & \multirow[t]{3}{*}{17.6} & $\begin{array}{l}\mathrm{C} 17, \mathrm{C} 22, \\
\mathrm{C} 24, \mathrm{C} 25 \\
\mathrm{C} 31, \mathrm{C} 33\end{array}$ & ${ }^{23} \mathrm{Na}^{+},{ }^{39} \mathrm{~K}^{+},{ }^{40} \mathrm{Ca}^{+},{ }^{56} \mathrm{CaO}^{+}$ & ${ }^{16} \mathrm{O} /{ }^{17} \mathrm{OH}^{-},{ }^{46} \mathrm{NO}_{2}^{-},{ }^{62} \mathrm{NO}_{3}^{-}$ \\
\hline & & & $\begin{array}{l}\mathrm{C} 21, \mathrm{C} 26 \\
\mathrm{C} 32\end{array}$ & ${ }^{23} \mathrm{Na}^{+},{ }^{39} \mathrm{~K}^{+}$ & ${ }^{16} \mathrm{O} /{ }^{17} \mathrm{OH}^{-},{ }^{46} \mathrm{NO}_{2}^{-},{ }^{62} \mathrm{NO}_{3}^{-}$ \\
\hline & & & $\mathrm{C} 29$ & ${ }^{23} \mathrm{Na}^{+},{ }^{62} \mathrm{Na}_{2} \mathrm{O}^{+},{ }^{165} \mathrm{Na}_{3} \mathrm{SO}_{4}^{+}$ & $\begin{array}{l}{ }^{16} \mathrm{O} /{ }^{17} \mathrm{OH}^{-},{ }^{46} \mathrm{NO}_{2}^{-},{ }^{62} \mathrm{NO}_{3}^{-}, \\
{ }^{131} \mathrm{NaNO}_{2} \mathrm{NO}_{3}^{-}\end{array}$ \\
\hline
\end{tabular}


Table 2. Average factor contributions as measured by the ATOFMS and resolved by PMF during the BAQS-Met campaign.

\begin{tabular}{lcc}
\hline \multirow{2}{*}{ Factor } & \multicolumn{2}{c}{ Particle Number Concentration } \\
\cline { 2 - 3 } & (Particles/Hour) & $(\%)$ \\
\hline Long Range Transport & 12.6 & 9.8 \\
Fireworks & 14.6 & 11.3 \\
Organic & 15.1 & 11.8 \\
Biomass Burning 1 & 14.7 & 11.4 \\
Biomass Burning 2 & 12.6 & 9.8 \\
ECOC Day & 19.5 & 15.1 \\
ECOC Night & 17.2 & 13.4 \\
Nitrate Background & 10.8 & 8.4 \\
Nitrate Dust & 11.5 & 9.0 \\
\hline
\end{tabular}

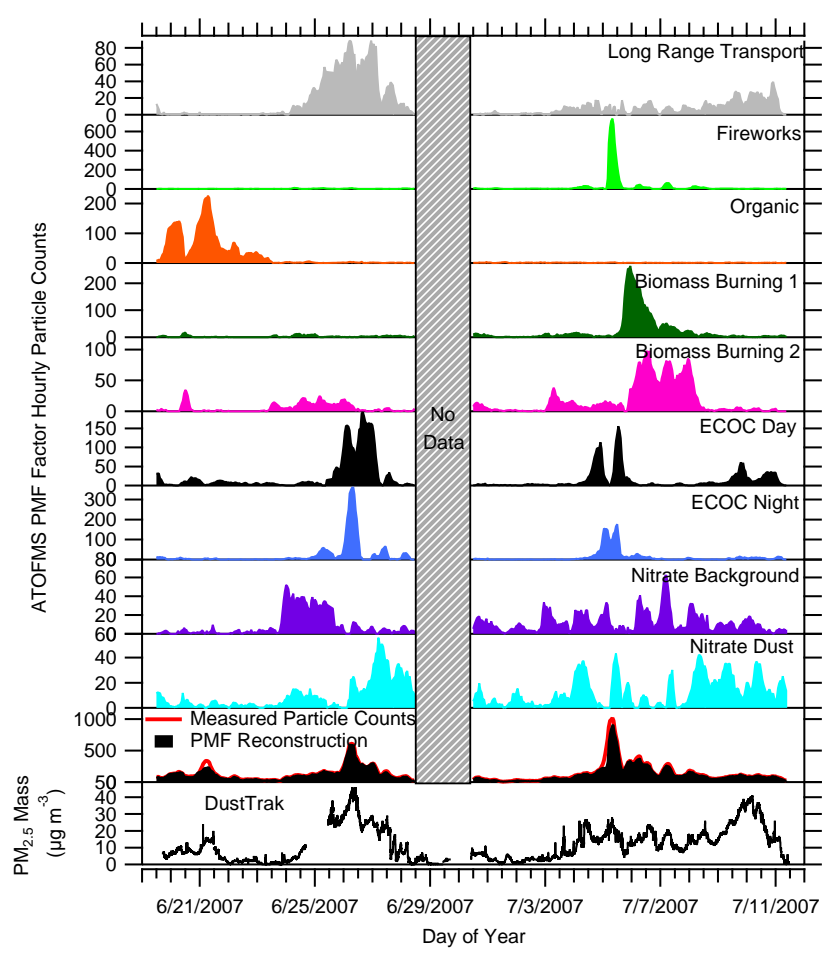

Fig. 2. Time series of the nine PMF factors' hourly particle counts and the DustTrak PM $_{2.5}$ mass. No ATOFMS data was available for PMF analysis between approximately 12:00, 28 June and 12:00, 30 June as the ultrafine aerodynamic focusing lens (AFL030) was used at that time.

particle-types to the factors from the nine factor solution are shown in Figs. 2 and 3 respectively. Given that some factors appeared to be related, an objective justification for this PMF solution is provided below.

In general, a PMF solution is chosen as the solution for which increasing the number of factors ceases to explain any more significant variability in the dataset. Beyond this point there is a risk of factor splitting (Ulbrich et al., 2009), which

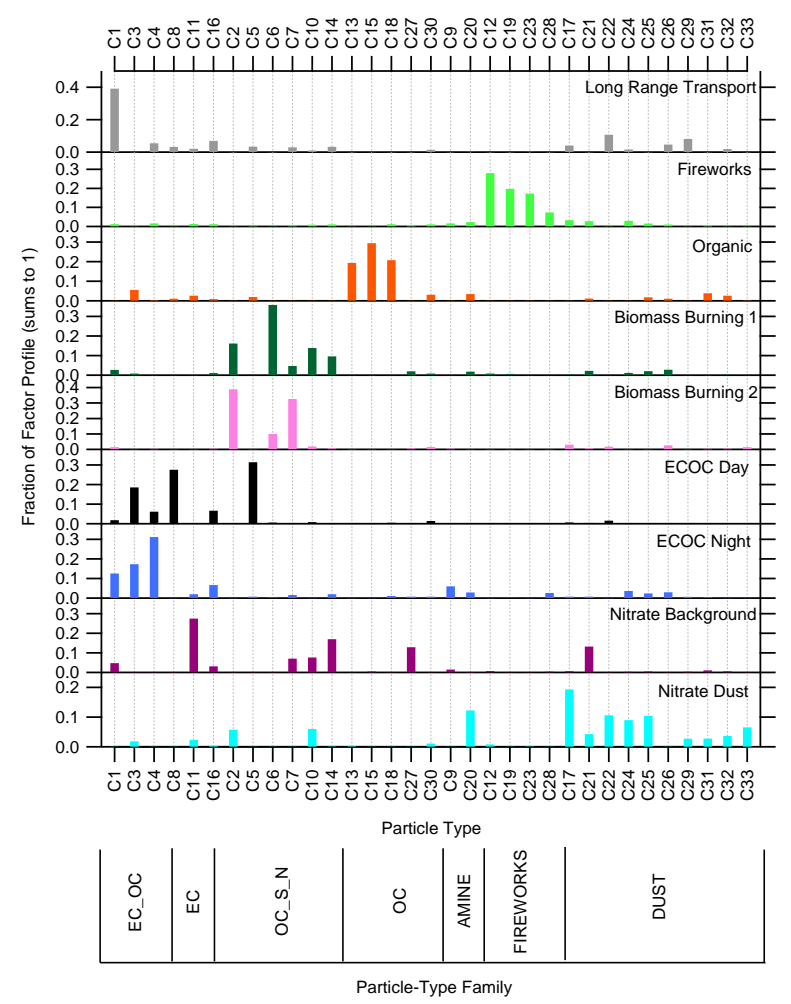

Fig. 3. Factor particle-type profiles of the nine PMF factors. To facilitate discussion of the particle-type apportionment, particle-types have been grouped on the lower axis based on their corresponding families.

may lead to less physically meaningful, or even uninterpretable results. First, the explained variance was analyzed by comparing the reconstructed data with measured particle counts per hour by performing linear regression analysis. The coefficient of determination $\left(R^{2}\right)$ from regression analysis was used to examine the degree to which additional factors impacted the explained variance in the measured particle counts. The explained variance was also examined in terms of the uncertainties through examination of the $Q_{\text {robust }} / Q_{\exp }$ parameter. Second, to obtain further insight into the temporal "contribution" of the variability captured by additional factors, the time-resolved difference in $Q\left(\Delta Q_{\text {cont }}\right)$ between two adjacent solutions, as detailed by (Slowik et al., 2010), was examined:

$\Delta Q_{\text {cont }}=\left(\sum_{j}^{m}\left(e_{i j} / s_{i j}\right)^{2}\right)_{p}-\left(\sum_{j}^{m}\left(e_{i j} / s_{i j}\right)^{2}\right)_{p+1}$

Third, the effect of the addition of factors on existing ones was determined by performing correlation analysis. In this analysis, the Pearson product-moment correlation coefficient $(r)$ was calculated between the time series of highly comparable factors in adjacent PMF solutions (Table 3). An 
Table 3. Pearson $r$ correlation coefficients for the time series of factors of PMF solution $p$ and $p+1$.

\begin{tabular}{|c|c|c|c|c|c|c|}
\hline \multirow[b]{2}{*}{ Factor Name } & \multicolumn{6}{|c|}{ Factor Transition } \\
\hline & $p=4 \rightarrow p=5$ & $p=5 \rightarrow p=6$ & $p=6 \rightarrow p=7$ & $p=7 \rightarrow p=8$ & $p=8 \rightarrow p=9$ & $p=9 \rightarrow p=10$ \\
\hline ECOC Day & 1.00 & 0.94 & 0.98 & 1.00 & 0.98 & 1.00 \\
\hline Biomass Burning 1 & 1.00 & 1.00 & 1.00 & 0.94 & 0.99 & 1.00 \\
\hline Nitrate Background & 0.96 & 0.95 & 0.98 & 0.98 & 1.00 & 0.84 \\
\hline Nitrate Dust & 0.98 & 0.97 & 0.83 & 1.00 & 0.93 & 1.00 \\
\hline Organic & New & 1.00 & 1.00 & 1.00 & 1.00 & 1.00 \\
\hline ECOC Night & & New & 0.94 & 1.00 & 0.99 & 1.00 \\
\hline Fireworks & & & New & 1.00 & 1.00 & 1.00 \\
\hline Biomass Burning 2 & & & & New & 1.00 & 1.00 \\
\hline Long Range Transport & & & & & New & 1.00 \\
\hline Nitrate New & & & & & & New \\
\hline
\end{tabular}

Note: shaded correlation coefficients imply that an existing factor's time series has been moderately $(0.90<r<0.95)$ or significantly $(r<0.90)$ influenced by the addition of a new factor.

effect was observed if the $r$ value decreased with the factor addition; a moderate effect was determined if $0.90<r<$ 0.95 , and a significant effect if $r<0.90$. Hence two different coefficients were used: the coefficient of determination $\left(R^{2}\right)$ to ascertain the variance in the measured particle counts that was explained by PMF modelled particle counts, and Pearson's $r$ to compare the degree of similarity between timeseries of like factors from adjacent PMF solutions. Lastly, bootstrapping was performed, and each PMF solution was initiated from 100 random starts or "seeds" to help determine its degree of uncertainty.

As seen in Fig. 4a, a minimum of four factors was required to explain greater than $60 \%$ of the explained variance $\left(R^{2}\right)$ in the measured particle counts. These factors were named based on their contributing particle-types as well as their temporality and were: ECOC Day, Biomass Burning 1, Nitrate Background and Nitrate Dust. Moving from $p=4$ to $p=5$ resulted in the addition of the Organic factor, and a small increase in the overall $R^{2}$ to $62 \%$. However, Fig. $4 \mathrm{~b}$ shows via the $\Delta Q_{\text {cont }}$ that this factor captured significant temporality in the signal at the beginning of the campaign. Correlation analysis with the previous factors showed that none were even moderately affected by the addition of the Organic factor, indicating that it was almost entirely pulled from the residuals. Adding a sixth factor led to the appearance of the ECOC Night factor. While this could be attributed to factor splitting of the ECOC Day factor, this original factor was only moderately affected by the addition of ECOC Night, as evidenced by $r=0.94$ between the $p=5$ and $p=6$ ECOC Day time series. The large $\Delta R^{2}$ observed (0.09) also indicated that the ECOC Night was largely added from the residuals. Increasing to $p=7$ resulted in the largest increase in the explained variance in the measured particle counts $\left(\Delta R^{2}=0.24, R^{2}=0.95\right)$; this was the result of a large spike on 5 July being captured, and as such it was termed the Fireworks factor. Comparison with the Nitrate Dust factors for $p=6$ and $p=7$ showed that this factor was significantly affected by the addition of the Fireworks factor. Further factor additions did not affect the $R^{2}$ as greatly and consequently a minimum of seven factors was required to provide an adequate explanation of variance. Shifting from $p=7$ to $p=8$ produced the most direct example of factor splitting: the Biomass Burning 1 factor was split into a slightly modified version of itself as well as the Biomass Burning 2 factor. Biomass Burning 1 was moderately affected by this new factor, as evidenced by the Pearson $r$ of 0.94 when comparing its temporality between the 7 and 8 factor solutions. No significant $\Delta R^{2}$ in explaining the measured particle counts occurred with this factor addition, although Fig. 4b shows that some temporality from the residuals was captured which is similar in temporality to the Biomass Burning 2 factor. While factor splitting generally indicates too many factors have been chosen, this particular split could be physically justified, as outlined later in Sect. 3.3.4. Furthermore, increasing $p$ to 9 factors produced the Long Range Transport factor. While this factor could be interpreted as splitting of the Nitrate Dust factor (Pearson $r$ for $p=8$ to $p=9$ of 0.93 between like factors in these PMF solutions, with a $\Delta R^{2}=0.02$ in the explained variance), a meaningful physical explanation could also be provided for this factor (Sect. 3.3.1). Beyond $p=9$, factor splitting continued to occur, particularly for the Nitrate Background factor which was significantly affected by the addition of a $10^{\text {th }}$ factor, and the additional factors could no longer be physically justified.

The mathematical robustness for the 8, 9 and 10 factor solutions was further examined through initiating PMF from 100 random starts, or "seed" values, as well as bootstrapping. The 9 factor solution appeared to provide a global minimum as the 100 different "seed" values produced identical $Q$ values $\left(Q_{\text {robust }} / Q_{\exp }=0.579\right)$. A similarly stable solution in terms of seeds was found for the 10 factor solution 

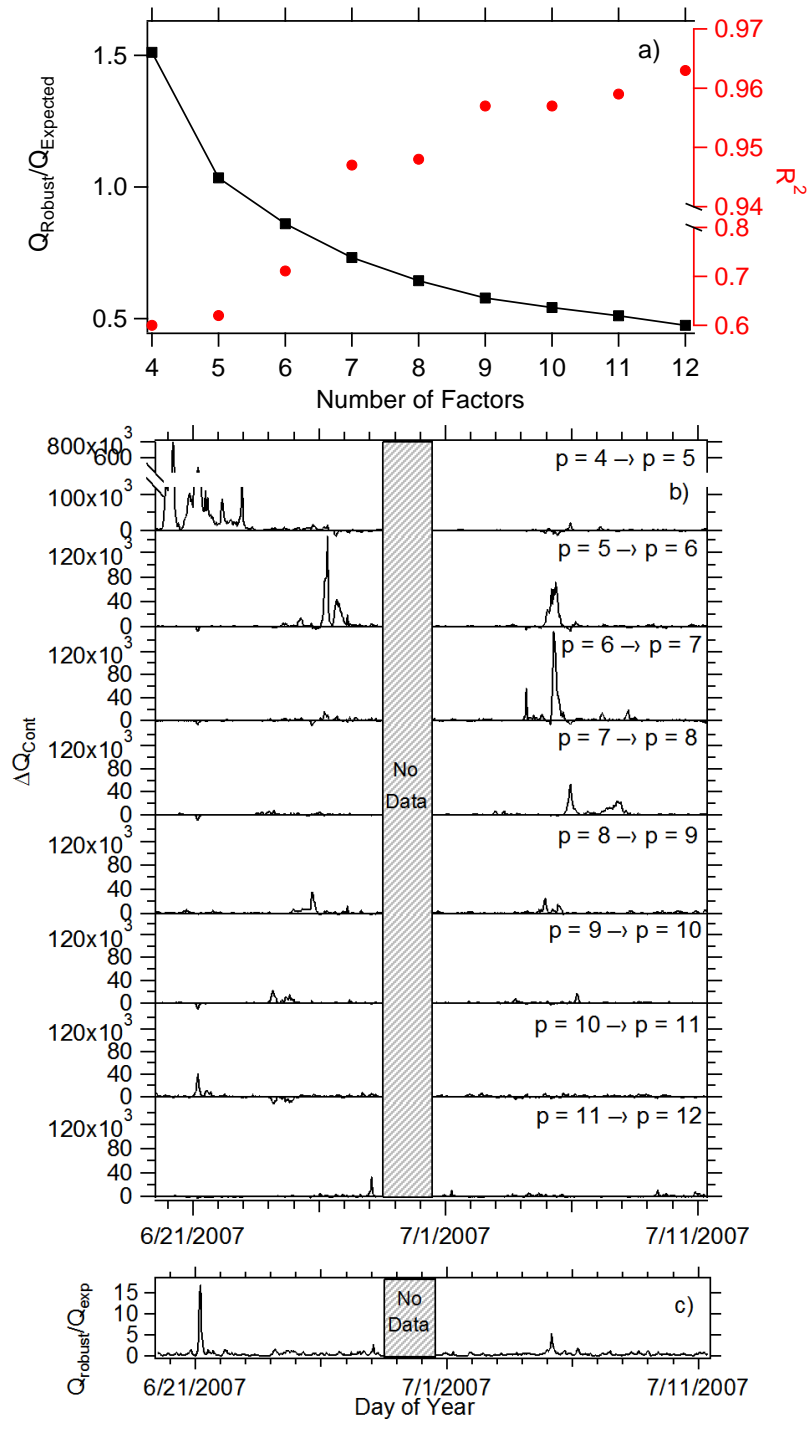

Fig. 4. The impact of increasing the number of factors $(p)$ in a PMF solution on the $R^{2}$ and robust $Q$ value (a); the incremental change in time-dependent contribution of the residuals to the $Q$ value upon addition of factors ( $\left.\Delta Q_{\text {cont }}\right)$ (b); and the time-dependent contribution of the robust $Q$ value normalized to the expected $Q$ value for the 9 factor solution (c).

( $Q_{\text {robust }} / Q_{\exp }$ of 0.542 for $100 \%$ of the seed values). By contrast, the 8 factor solution displayed two minima in the $Q$ values with $Q_{\text {robust }} / Q_{\text {exp }}$ s of $0.644(36 \%)$ and $0.669(64 \%)$. Bootstrapping was performed to further assess solution stability and uncertainty. This provided support for the 9 factor solution as it demonstrated the highest degree of similarity possible for these data and uncertainties between the bootstrapped results: $75 \%$ of the bootstrapped solutions were sufficiently similar to be "remapped" to the base case, while the same applied for only $52 \%$ and $54 \%$ of the 8 and 10 factor solutions.

Figure $4 \mathrm{c}$ shows the ratio of the $Q_{\text {robust }} / Q_{\text {exp }}$ over time. Two spikes are noticeable where the solution has failed to capture adequate temporality: first on 21 June at 04:00, and second on 5 July at 04:00 (all times are given in eastern daylight time (EDT)). In the first case, the residual was attributed to two particle-types which were not adequately modeled: C13 (OC_S_N family) and C30 (OC family). In the second case, it was attributed to a single particle-type, C9 (Amine). Regardless of downweighting these particle-types by $300 \%$, these two spikes could not be captured for $p \leq 12$, and as such they were left unweighted.

Rotational freedom was investigated by varying the FPeak parameter from -2.5 to 2.5 in increments of 0.5 . All solutions in this range were examined, although the solutions for FPeak of -0.5 and +0.5 were investigated most closely as they only resulted in a $Q_{\text {robust }} / Q_{\exp }$ difference of 5 and $15 \%$ respectively, which was within the recommended exploration range (Ulbrich et al., 2009). Neither of these solutions provided an improved physical interpretation or mathematically robust solution for the 9 factor solution, and consequently the central rotation with $F_{\text {Peak }}=0$ was chosen.

The characteristics and possible origin(s) of the nine reported factors were assessed systematically based on: particle-type external mixture; internal mixing state of the contributing particle-types; particle-type size distributions; factor temporality; and geographic origins. A factor was said to be weakly externally mixed if either one particle-type, or several highly similar particle-types (i.e. from the same family and similar in internal mixing state), dominated its factor profile. Conversely, if particle-types from several different families contributed to a factor, or if the particle-types within a contributing family were significantly different in their internal mixing (i.e. their single particle composition), it was deemed as strongly externally mixed. The following sections summarize the receptor modeling findings for each factor.

\subsubsection{Long Range Transport Factor}

The Long Range Transport Factor consisted of significantly aged, homogeneous aerosol transported from regional sources. This factor was generally observed at elevated concentration during the PM episodes (Fig. 2), suggesting these particles played a significant role in diminishing air quality during these periods. The PMF factor particle-type profile (Fig. 3) showed that it was mostly characterized by three highly-aged particle-types: C1 (EC_OC), along with smaller amounts of larger diameter particle-types C22 (DUST: aged sea-salt) and C29 (DUST: aged soil dust). Given the significant contribution from the most common particle-type, $\mathrm{C} 1$, as shown in Fig. 3, this factor appeared to be weakly externally mixed. Chemical processing was assessed based on internal mixing with secondary material within these particle-types. In particular, $\mathrm{C} 1$ contained the highest sulphate and ammonium content relative to EC among all particle-types containing a clear EC contribution (Fig. S3). 

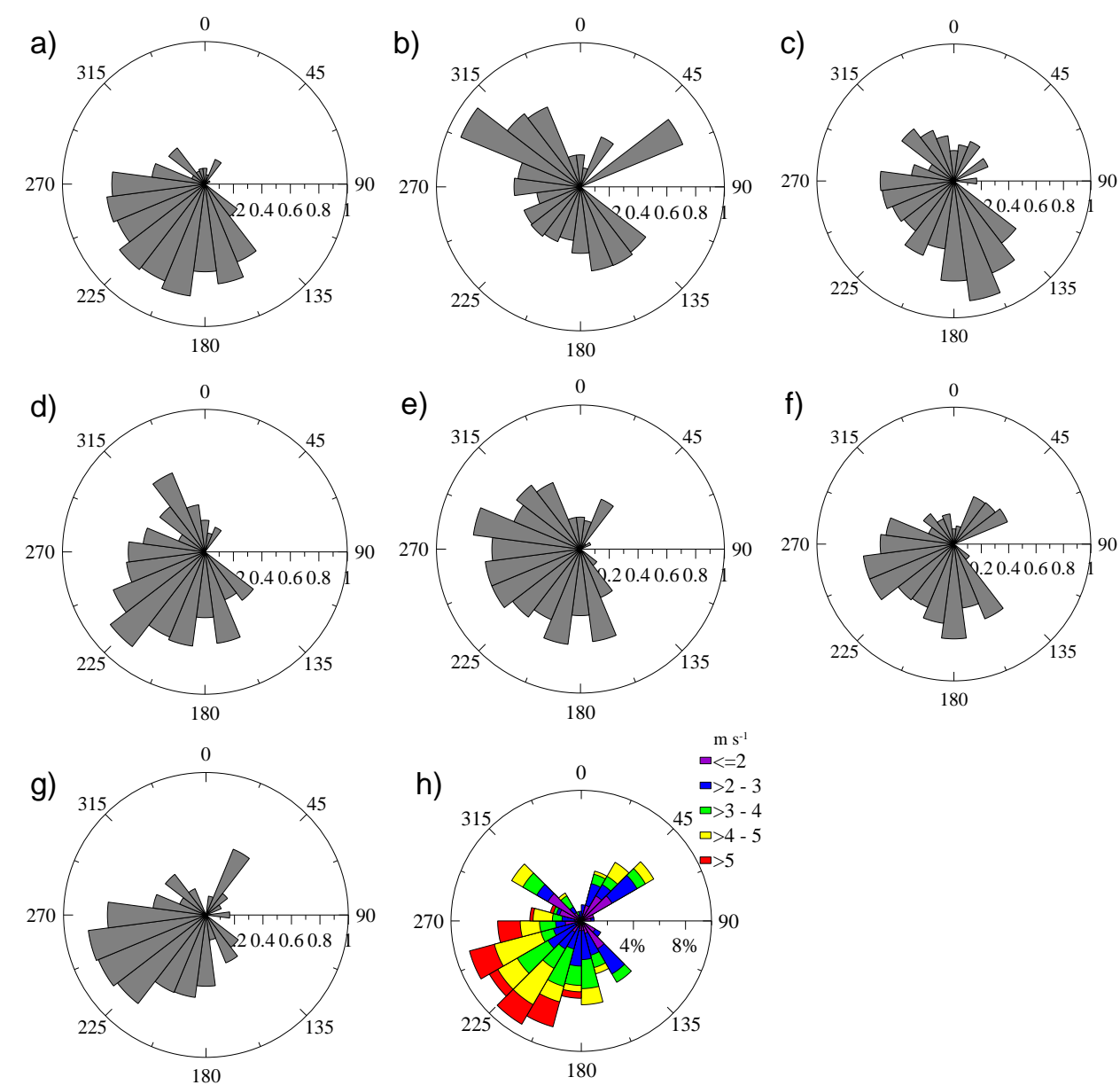

Fig. 5. CPF plots for the ATOFMS PMF factors: Long Range Transport (a), Organic (b), Biomass Burning 2 (c), ECOC Day (d), ECOC Night (e), Nitrate Background (f), Nitrate Dust (g). Also shown is a rose plot of wind speeds plotted by wind direction (h). Only factors with four or more days of significant particle counts are shown.

This particle-type also exhibited significant mass spectral contributions from oxidized organic fragments, namely $\mathrm{m} / \mathrm{z}$ $+43\left[\mathrm{C}_{2} \mathrm{H}_{3} \mathrm{O}^{+}\right]$and $\mathrm{m} / \mathrm{z}-89\left[(\mathrm{COO})_{2} \mathrm{H}^{-}\right]$. As particles are coated by secondary reaction products and agglomerate with one another during transport, they become less distinguishable by ATOFMS based on characteristic source tracer species (Pratt and Prather, 2009). Thus it is reasonable that at a semi-rural site the most aged particles in this size range would also be the most common. Significant chemical processing was also observed in both C22 and C29 as a result of their high nitrate contributions (Fig. S9), indicating reaction with nitric acid. This type of chemical processing of dust particle-types has been observed by ATOFMS at several other locations (Dall'Osto and Harrison, 2006; Sullivan et al., 2007; Healy et al., 2010).

The significant chemical processing and weak external mixing of this factor, suggested regional origins. To refine the geographic spatial scale, the CPF (Fig. 5a) and PSCF (Fig. 6a) were examined. The CPF showed directionality between the west to south of the site, which was also consistent with the synoptic, south-westerly regional air masses that typically influence south-western Ontario (OME, 2008). Due to the wide band of probable wind sectors between the west and the south, the CPF suggested that the emission location was likely regional. This was confirmed using the lowresolution PSCF, which identified numerous, high probability emission locations to the south and southwest. These potential source regions contain vast swaths of the Midwestern US, including Ohio, Illinois, Indiana and Missouri. The areas of highest probability were closer to the measurement site, and included regions containing either large cities or large coal-fired power plants.

In general, this factor was mostly associated with transport of air masses corresponding to backtrajectories from the south and southwest. Similar long range transport factors have been found in the few other PMF studies of SPMS particle-types. In Toronto, a sporadic, intercontinental dust factor was discovered, which was attributed to Saharan dust 

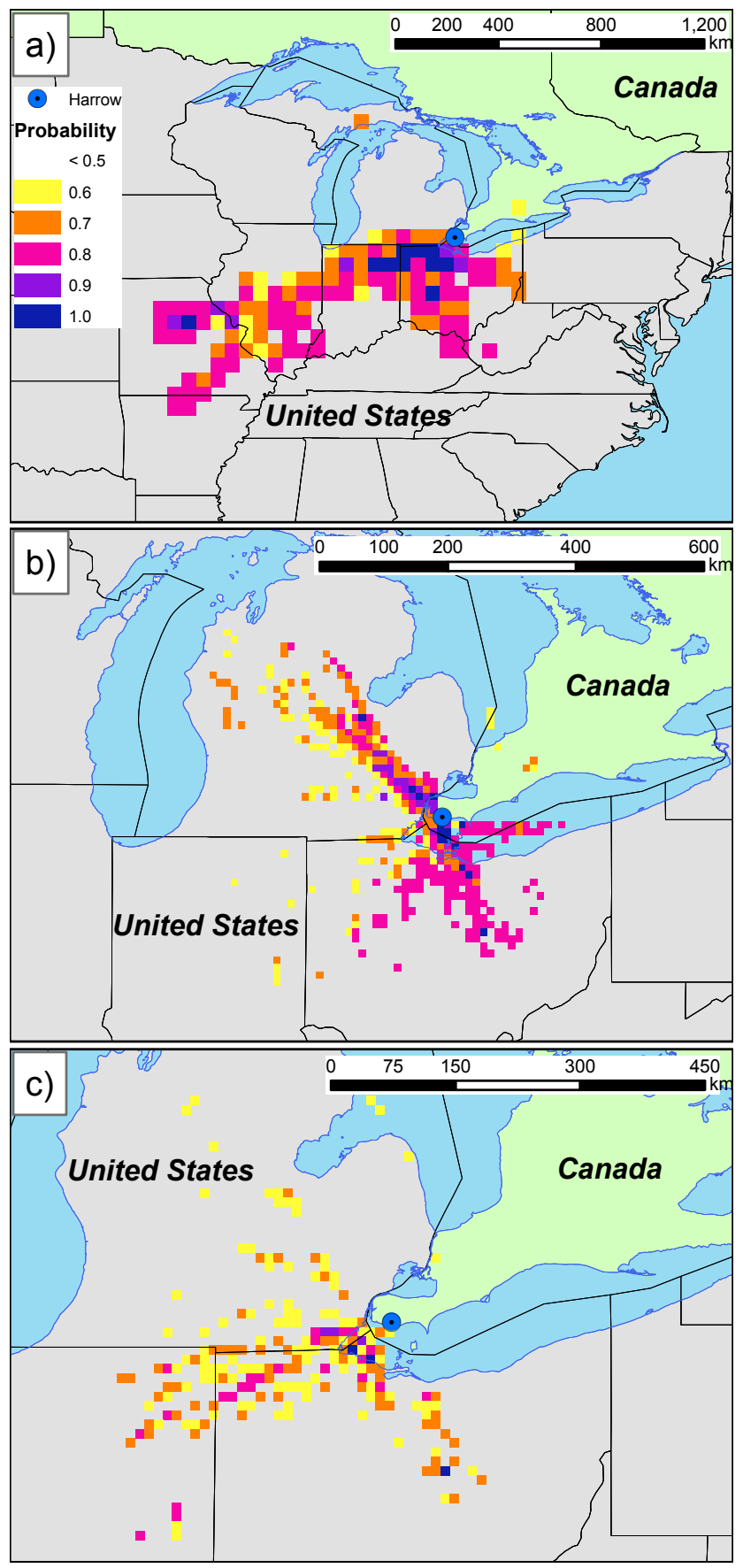

Fig. 6. Low resolution PSCF plot for the Long Range Transport factor (a) and high resolution PSCF plots for the Biomass Burning 2 (b) and ECOC Day (c) factors. Areas of higher probability indicate more probable source regions.

from Africa (Owega et al., 2004). A factor named Long Range Transport was also identified by Healy et al. (2010) in a receptor modelling study in Cork, Ireland on the Irish coast. In that study, the transported particles contained similar components as those found in the present study (e.g. elemental carbon, organic carbon, sulphate), yet due to transport over a marine environment, they also contained significant sea salt and methanesulphonate.

An interesting feature of this Long Range Transport factor was its similarity, in both chemical profile and geographic origins, to a regional Secondary Sulphate factor extracted through a long-term receptor modelling of 24-h filter measurements from nearby Windsor (Jeong et al., 2011b). Such a similarity across measurement sites reinforced the regional nature of this factor. In summary, the Long Range Transport factor consisted of particle-types from a variety of distant sources to the south and southwest that had undergone significant chemical processing during transport, ultimately leading to greater homogeneity in their composition (i.e. weaker external mixing).

\subsubsection{Fireworks factor}

The Fireworks PMF factor temporal trend and particle-type profile are shown in Figs. 2 and 3 respectively. A large spike in ATOFMS particle counts recorded in the early morning on 5 July was attributed to the Fireworks factor (Fig. 7a). This factor was mostly associated with this one spike, which occurred at Harrow only several hours after 4 July US Independence Day fireworks displays across the international border. Due to the episodic appearance of this factor, the $\mathrm{CPF}$ and PSCF could not be used to determine its geographic origins; accordingly CMC generated high-resolution backtrajectories corresponding to the 5 July episode were used (Fig. 7b). Figure $7 \mathrm{~b}$ shows that the 5 July episode air mass swept over the Detroit metropolitan area at approximately 22:00 on 4 July, which corresponded to the expected time of holiday fireworks displays. Data to support the claim that this factor was associated with emissions from in and around Detroit was provided by the c-ToF-AMS in Harrow, and the Q-AMS deployed in Windsor. Each of these instruments registered extreme spikes in $\mathrm{K}^{+}$measurements around the same time, as shown in Fig. 7a. At Harrow, the $\mathrm{K}^{+}$spike occurred simultaneously with the Fireworks factor; at Windsor, the spike occurred at 22:00, consistent with the expected timing of fireworks deployment (note that $\mathrm{K}^{+}$is provided in arbitrary units because of the semi-quantitative nature of the measurement). While $\mathrm{K}^{+}$is emitted in high concentration with biomass burning (Qin and Prather, 2006), $\mathrm{K}^{+}$is also a good marker for fireworks emissions (Drewnick et al., 2006). These data suggested that emissions associated with this factor originated around Detroit, or upstream, and swept over Harrow several hours later.

The size distribution and internal mixing state of the contributing particle-types provided evidence for an association with pyrotechnic emissions. Each of the Fireworks factor particle-types displayed a large geometric mean diameter (average $D_{\mathrm{va}}=0.86 \mu \mathrm{m}$ ). In terms of composition, as detailed in Fig. S8, these particle-types were internally mixed with inorganic cations such as $m / z \mathrm{~s}+39\left[\mathrm{~K}^{+}\right], m / z+23$ $\left[\mathrm{Na}^{+}\right],+24\left[\mathrm{Mg}^{+}\right],+27\left[\mathrm{Al}^{+}\right],+40\left[\mathrm{Ca}^{+}\right]$, which when taken 

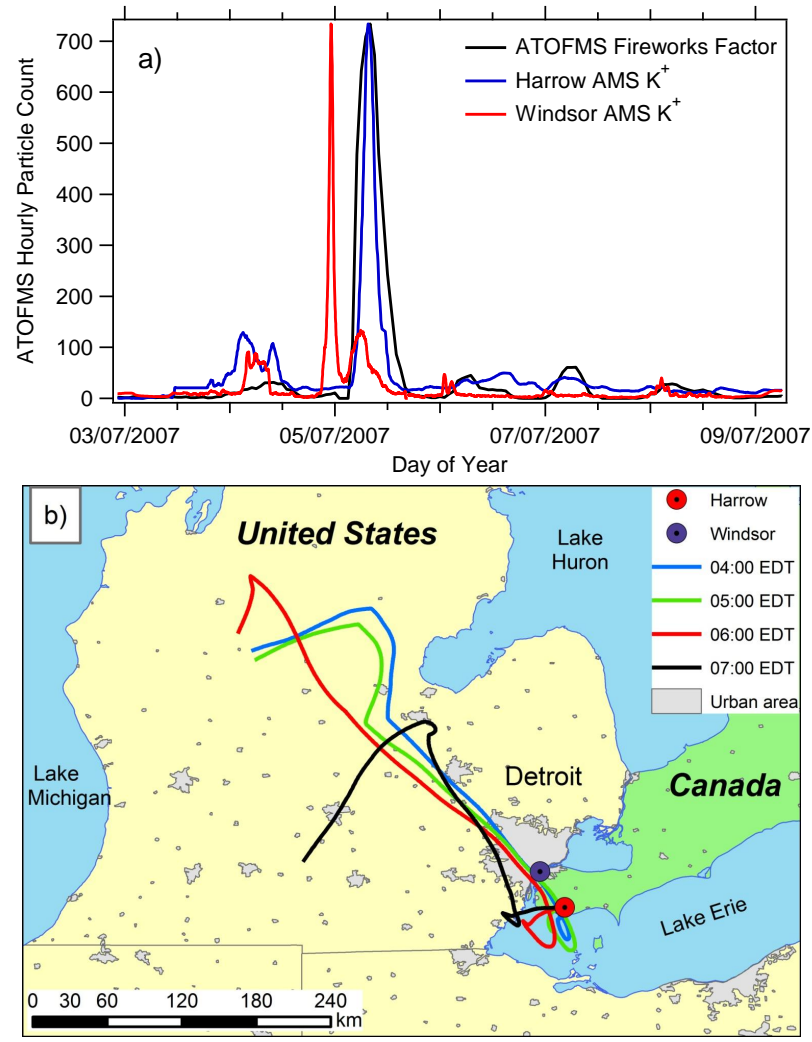

Fig. 7. Impact of the ATOFMS Fireworks factor and AMS $\mathrm{K}^{+}$in both Harrow and Windsor (a), (AMS $\mathrm{K}^{+}$in arbitrary units). Shown in (b) are high-resolution Harrow backtrajectories during the 5 July Fireworks factor spike.

together in such high mass spectral contributions, were consistent with ambient fireworks emissions (Liu et al., 1997; Moreno et al., 2007; Vecchi et al., 2008; Joly et al., 2010). Moreover, the dominant particle-type C12 (FIREWORKS), contained all the aforementioned ions, as well as minor contributions from ions more characteristic of fireworks emissions (e.g. $m / z \mathrm{~s}+63 / 65\left[\mathrm{Cu}^{+}\right],+88\left[\mathrm{Sr}^{+}\right],+138\left[\mathrm{Ba}^{+}\right]$, and $\left.+154\left[\mathrm{BaO}^{+}\right]\right)$; this particle-type was highly similar to particles measured in a fireworks plume in Riverside, California (Liu et al., 1997). These particle-types were notably different from the DUST family types due to these ionic contributions, as well as a smaller diameter range $(0.84-0.88 \mu \mathrm{m})$ as compared to that of the DUST family $(0.64-1.42 \mu \mathrm{m})$. Some primary nitrate contributions were also suspected as $\mathrm{KNO}_{3}$, or "black powder", is used as the pyrotechnic oxidizing agent in fireworks (Drewnick et al., 2006). Evidence suggesting such contributions was given by peaks at $m / z+140\left(\mathrm{~K}_{2} \mathrm{NO}_{3}^{+}\right), \mathrm{m} / z$

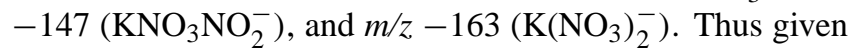
their distinct mass spectra, their diameter relative to other particle-types, and episodic appearance early on 5 July, it can be concluded that this PMF factor and its corresponding particle-types were related to Independence Day fire- works emissions, likely from the Detroit metropolitan area and south-east Michigan.

\subsubsection{Organic factor}

PMF analysis identified a factor consisting of particle-types arising from an organic emissions source class that could not be positively identified; as such, this factor was named Organic. Its particle-type PMF factor temporal trend and profile are shown in Figs. 2 and 3 respectively. This factor contained significant organic material, and was likely emitted by a combustion source relatively close to the measurement site. Figure 8 describes the organic nature of this factor. When this factor was present, it was highly correlated with measurements of organic carbon and elemental carbon measurements from collocated EC/OC measurements (Sunset OCEC Analyzer), as well as $\mathrm{NO}_{2}$, the latter two being tracers for combustion emissions. Examination of the three dominant particle-types (e.g. C13, C15, and C18 - OC family), all illustrated in Fig. S6, revealed that they all had similar size distributions (mean $D_{\mathrm{va}}=0.55-0.58 \mu \mathrm{m}$ ), and very similar mass spectra. Thus, taken together, they exhibited weak external mixing. Significant chemical processing was unlikely for these particle-types given the lack of signal in the negative ion mass spectrum. Most of the organic fragments contained in these particle-type mass spectra were similar to those from other particle-types enriched in organic carbon, such as $m / z \mathrm{~s}+27\left[\mathrm{C}_{2} \mathrm{H}_{3}^{+}\right]$and $+43\left[\mathrm{C}_{2} \mathrm{H}_{3} \mathrm{O}^{+}\right]$, indicative of oxidized organic species. However these particle-types were distinct due to significant peaks at $\mathrm{m} / \mathrm{z}+63,77$, and 91 , a fragmentation pattern consistent with fresh aromatic hydrocarbon emissions (Liu et al., 2003; Qin and Prather, 2006). These particle-types, which were entirely apportioned to this factor, displayed high $\left[\mathrm{K}^{+}\right]$peaks in their mass spectra, in addition to the positive organic carbon ion contributions. Such a combination typically suggests a biomass burning combustion source (Silva et al., 1999; Qin and Prather, 2006). Yet the expected associated levoglucosan peaks in the negative ion mass spectrum were insignificant, preventing a positive identification as such.

The identity of the Organic factor was further explored using the PSCF and CPF, so as to discern its geographic origins relative to the receptor site. As the PSCF's were inconclusive, probable areas of regional sources could not be determined. However, this factor's CPF (Fig. 5b) highlighted the possibility of either a local or local-to-regional source to the north-west. A source location within this spatial scale was further supported by the inferred lack of significant chemical processing in this factor's dominant particle-types. Ultimately, the source was not suspected to be highly local, as this factor was better correlated with $\mathrm{NO}_{2}$ than shorter-lived NO. Even though this unknown combustion emissions factor was observed only at the beginning of the campaign, from 19-23 June 2007, it dominated by far the particles measured 


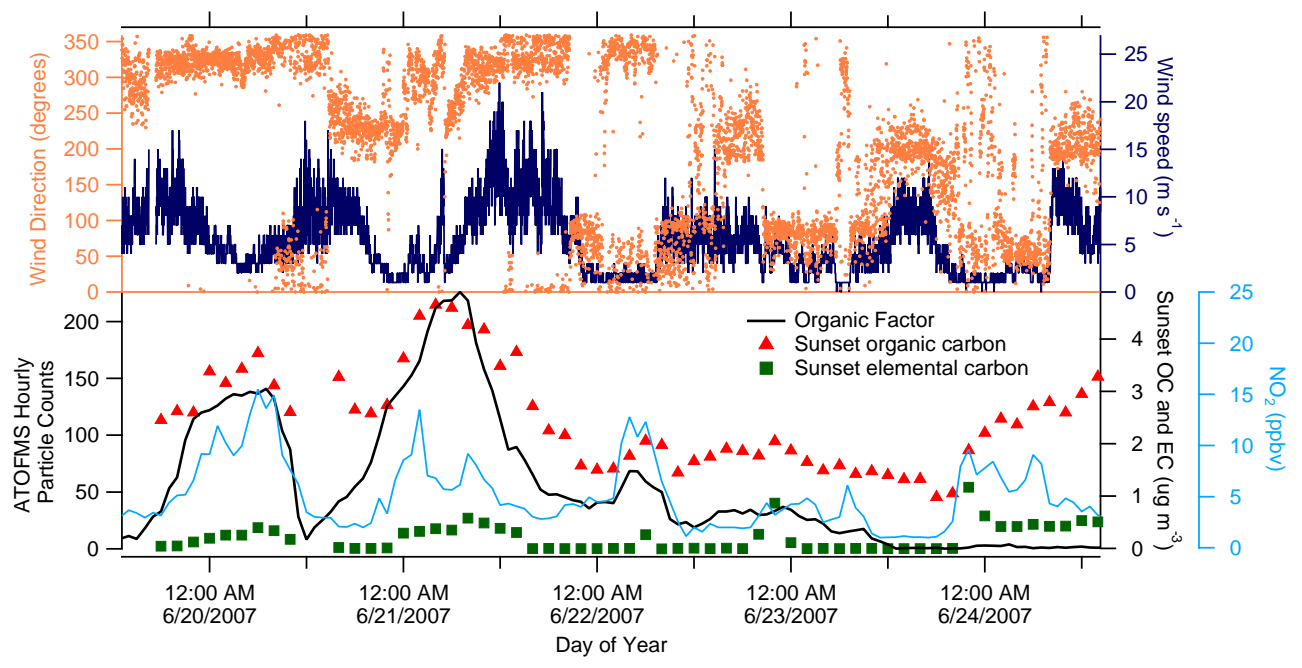

Fig. 8. Temporal trend of the Organic factor in relation to the hourly average $\mathrm{NO}_{2}$ mixing ratio and Sunset organic carbon and elemental carbon mass concentrations. Only the first few days of the study period when this factor's concentrations were high are shown.

by the ATOFMS during this time, and thus likely had a significant bearing on air quality in the region.

\subsubsection{Biomass burning factors}

Two biomass burning factors, Biomass Burning 1 (BB1) and Biomass Burning 2 (BB2) were identified by PMF analysis and their factor temporal trends and PMF particle-type profiles are shown in Figs. 2 and 3 respectively. These factors both appeared to originate from forest fires, yet were separated by PMF due to differences in chemical processing. While the exact locations of the forest fires contributing to these factors could not be identified, a case study for 5 July showed that at least on that day, these factors were impacted by fires in Northern Ontario and Manitoba. Furthermore, a meso-analysis of meteorology on that day revealed that thunderstorm activity may have led to the observed differences in chemical processing. The following paragraphs discuss these findings in further detail.

The particle-types associated with the biomass burning factors arose almost exclusively from one family, namely OC_S_N, and they all displayed similar size distributions (average $D_{\mathrm{va}}=0.59 \mu \mathrm{m}$ ). Figure 3 demonstrates that of the two factors, BB1 appeared to be more strongly externally mixed in that it was characterized by a mixture of numerous particle-types from this family, specifically C2, C6, C7, $\mathrm{C} 10$, and $\mathrm{C} 14$. By contrast, BB2 appeared to be a weaker external mixture, as it was defined by fewer particle-types, namely $\mathrm{C} 2$, C6, and $\mathrm{C} 7$ (all also $\mathrm{OC} \_\mathrm{S} \_\mathrm{N}$ ). The particletype PMF factor profiles and their corresponding temporal trends indicated that these two factors were related. Their shared particle-types from the same family, suggested that they originated from a common source class. Biomass burning emissions were proposed as the source class given that all the corresponding particle-types closely resembled particles generated from source characterization studies (Silva et al., 1999; Healy et al., 2010), and satisfied three defining criteria: large $\left[\mathrm{K}^{+}\right]$peaks, large organic carbon signals in the positive ion mass spectrum, and clear contributions from organic acid fragments, such as formate, $\mathrm{m} / \mathrm{z}-45$ $\left[\mathrm{CHO}_{2}^{-}\right]$, and acetate, $-59\left[\mathrm{C}_{2} \mathrm{H}_{3} \mathrm{O}_{2}^{-}\right]$. These organic acid ions are consistent with the fragmentation of levoglucosan, a product of biomass combustion, upon desorption and ionization by the ATOFMS (Silva and Prather, 2000). Significant contributions from secondary inorganic species, such as $m / z-97\left[\mathrm{HSO}_{4}^{-}\right], m / z-46\left[\mathrm{NO}_{2}^{-}\right]$, and $m / z-62\left[\mathrm{NO}_{3}^{-}\right]$, indicated that these factors' characteristic particle-types experienced chemical processing. Oxidized organic fragment ions, such as $m / z+43\left[\mathrm{C}_{2} \mathrm{H}_{3} \mathrm{O}^{+}\right]$, suggested the presence of secondary organic compounds. The degree of chemical processing observed in these two factors indicated that they were likely not local biomass burning emissions, thus excluding any local agricultural burning. Accordingly these factors were likely from either local-to-regional or regional forest fire emissions. A similar factor has been previously identified through PMF of ATOFMS particle-types obtained in Toronto and was found to be the result of regional forest fires in Québec and the Canadian Prairies (Owega et al., 2004).

Although the BB1 and BB2 factors were chemically similar, and seemingly resulted from factor splitting (see Sect. 3.3), there were distinct differences in the internal mixing state of their characteristic particle-types. It was first noted that, on the whole, particle-types characterizing BB2 exhibited a higher $\left[\mathrm{HSO}_{4}^{-}\right] /\left[\mathrm{K}^{+}\right]$ratio in comparison to those describing $\mathrm{BB} 1$, indicating greater chemically processing. This conclusion was supported by a weaker external mixture observed for BB2, whereby the accumulation of secondary species caused the particles to appear more similar. Second, 
the characteristic particle-types of the BB2 factor, $\mathrm{C} 2, \mathrm{C} 6$, and $\mathrm{C} 7$, all exhibited markedly higher peaks at $\mathrm{m} / z-195$ $\left[\mathrm{H}\left(\mathrm{HSO}_{4}^{-}\right)_{2}\right]$, a marker for sulphuric acid. Sulphuric acid originates either from homogeneous oxidation of $\mathrm{SO}_{2(\mathrm{~g})}$ in the gas phase with subsequent condensation onto particle surfaces (Seinfeld and Pandis, 2006), from heterogeneous production on particle surfaces from fresh, local emissions (Ault et al., 2010), or from uptake of $\mathrm{SO}_{2(\mathrm{~g})}$ and subsequent oxidation in the aqueous phase (Whiteaker and Prather, 2003). For this study, uptake and subsequent aqueous phase oxidation of $\mathrm{SO}_{2(\mathrm{~g})}$ was hypothesized to be the dominant mechanism, as will be discussed below. The BB1 factor exhibited its highest concentrations on $5 \mathrm{July}$, and its decrease in concentration later in that day corresponded with an increase in the BB2 factor. Given this inverse temporality on 5 July, as well as BB2 exhibiting a greater degree of chemical processing than BB1, it was hypothesized that particles from the BB1 factor (which was predominant on 5 July) may have been chemically transformed into those representative of the BB2 factor.

In addition to the CPF and PSCF, the geographic origins of these factors were investigated satellite fire detection data. Fire detects were obtained from NASA's Geostationary Operation Environmental Satellite (GOES) processed through the Automated Biomass Burning Algorithm (ABBA). Only the BB2 factor was used for statistical analysis as it appeared in significant concentration over the duration of the campaign. Given the complex meteorological conditions observed on 5 July, when these two factors temporality appeared inversely, the high resolution (HR) PSCF was used. The CPF for the BB2 factor suggested a source region to the south-east (Fig. 5c). While this was supported by hotspots observed in that direction in the HR PSCF (Fig. 6b), many of these hotspots were constrained to directly over Lake Erie, suggesting stagnation over the lake. Many local-to-regional and regional scale fires were burning during the BAQS-Met campaign in all directions at various times during the campaign, including the south-east. However, PSCF hotspots were also noted to the northwest of the measurement site over Michigan, hotspots which were influenced by the high concentrations recorded on 5 July. No forest fires were detected in these regions on or before 5 July, although very large fires were burning for the majority of the campaign in northern Ontario and Manitoba, further to the north-west. The "analyzed smoke" fire product from ABBA showed that smoke plumes from these fires influenced the BAQS-Met region only on a few occasions, one of which was 5 July. The hotspots observed to the north-west of Harrow in the PSCF appear to follow a trajectory in line with air masses which passed over the Canadian Prairies 48-h previously. Thus, as BB1 was only observed in significant concentration on 5 July, it is possible that these particles originated mostly from these fires to the distant north-west, while BB2 may have also had contributions from other fires in the region.

The spike in the BB1 factor's temporal trend, as well as the transition to the BB2 factor on 5 July, could be physically explained by examining the impacts of thunderstorms, which are commonly observed in the BAQS-Met study region (Sills et al., 2011). Mesoscale meteorological analyses were used to illustrate the impacts of thunderstorms on 5 July (details on how these analyses were produced can be found in Sills et al., 2011). Figure 9a highlights the passage of two gust fronts at the Harrow site, each marking the leading edge of thunderstorm downdraft air at the surface. These gust front passages were characterized by rapid temperature decreases (up to $5^{\circ} \mathrm{C}$ ), large increases in RH (up to $25 \%$ ), and winds gusting up to $7 \mathrm{~m} \mathrm{~s}^{-1}$. The first gust front passage was associated with a thunderstorm that developed north-west of Detroit after 13:00 EDT. This front moved rapidly southeast and was observed at Harrow at 16:30 (Fig. 9b), corresponding with the rapid rise in the BB1 factor. As mentioned previously, forest fire emissions from distant fires over northern Ontario and Manitoba were observed over northern Michigan mainly on 5 July. It is possible that downdrafts associated with this thunderstorm brought these particles to ground level from aloft. A second thunderstorm developed, again to the northwest of Detroit, after 16:00, and its gust front also moved rapidly to the south-east, passing Harrow at 20:30 (Fig. 9c). This was coincident with the onset of the shift to the BB2 factor. Two explanations can describe how these thunderstorms may have led to the differences in chemical processing observed in BB1 and BB2, namely that BB2 was enhanced secondary species such as sulphate, and was more acidic. First, the 4-h difference between these two factors may have provided enough time for particles, even aloft, to have become more chemically processed. Second, a slight difference in path taken for these two storms may have provided the necessary conditions:the most intense area of the first storm passed just south of Detroit, while the second travelled through its industrialized core. Thus, emissions of $\mathrm{SO}_{2(\mathrm{~g})}$ from sources in Detroit may have led to enhanced levels of sulphate deposition onto BB2 particles. As the BB2 factor was more common than BB1, this particle-type chemistry appeared more typical for the region. These two biomass burning factors provide not only an example of how thunderstorms can bring rapid changes in particle composition, but also demonstrate the power of particle-type-based PMF analysis for eliciting such changes.

\subsubsection{ECOC factors}

The ECOC Day and ECOC Night factors were found to have similar emissions origins, namely a carbonaceous local-toregional source emitted around Lake Erie. Although as with the biomass burning factors these two factors appear to have been justifiably separated by PMF. The following paragraphs describe the reasons for this separation in more detail.

In general, the strongest evidence for a similar emissions origin was the concurrent appearance of these factors during PM episodes (Fig. 2), and the respective cross-apportionment of particle-types from the same particle-type family (EC_OC) 

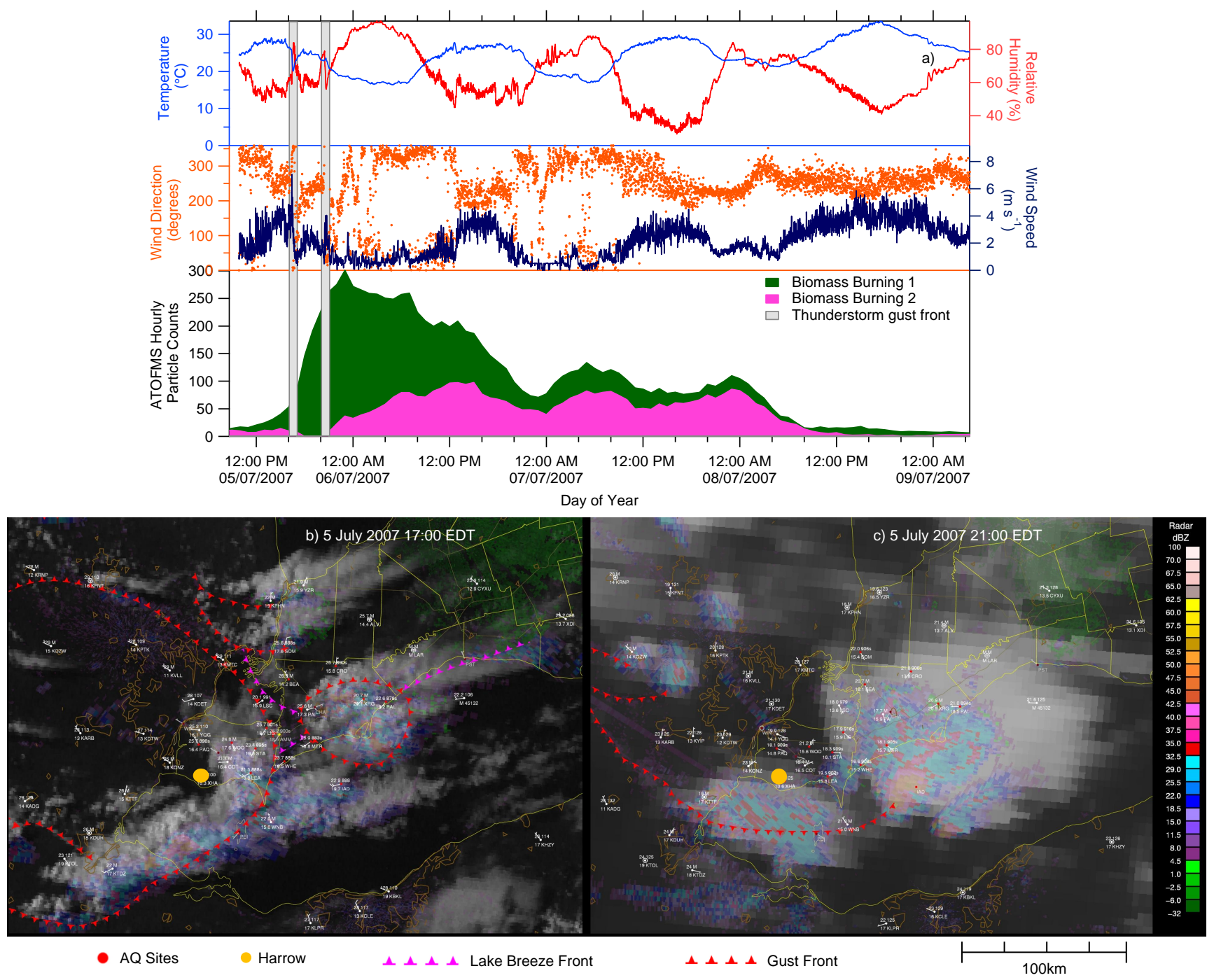

Fig. 9. Stacked time series of the two Biomass Burning factors (a), and meso-analysis images showing the passage of two thunderstorm gust fronts over Harrow on 5 July 2007 at 17:00 EDT (b) and 21:00 EDT (c).

(Fig. 3). Furthermore, all particle-types from this family displayed very similar size distributions, with a geometric mean $D_{\text {va }}$ of $0.68 \mu \mathrm{m}$. However, the strongly opposing diurnal trends of these factors indicated that they were different (Fig. 10), a difference which gave rise to their respective names. Whereas a mathematical justification for this separation was provided in Sect. 3.1, the following paragraphs aim to describe the physical reasons supporting this separation.

As shown in Fig. 10, the ECOC Day factor, on average, showed rapid rises in its concentration at around 09:00. These rises were, for the most part, consistent with the onset of the nocturnal inversion break down, as indicated by increased wind speeds beginning at approximately 08:00. This suggested that higher concentrations aloft may have been mixed in through the depth of the developing boundary layer. However, on several mornings (i.e. 26 and 27 June, and 9
July), these rises also corresponded to lake breeze front passages observed at Harrow, suggesting this factor may have been associated with the entrainment of particles into the Lake Erie basin and subsequent stagnation during the nighttime. The spatial scale of emission was examined using the CPF and PSCF; the HR PSCF was used as both the potential lake breeze and nocturnal inversion influences suggested the emission location may have been relatively close. The CPF indicated a potential source direction to the south-west (Fig. 5d) which was confirmed through backtrajectory analysis by the HR PSCF (Fig. 6c). The locations of highest emission probability were limited primarily to the western and southern shores of Lake Erie, suggesting contributions from large industrial sources, including coal-fired power plants, and large cities such as Toledo. However, the HR PSCF also indicated that influences from more far reaching sources to 


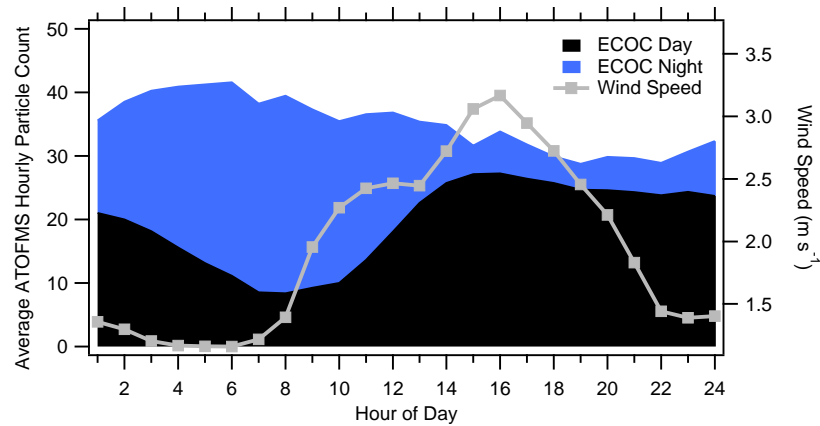

Fig. 10. Stacked diurnal trends for the ECOC Day and ECOC Night factors, along with the campaign diurnal averaged wind speed (the early morning peak beginning at 06:00 and ending at 17:00 on 5 July was removed from the calculation of the ECOC Night factor diurnal trend to highlight the trend present for other peaks).

the south-west were also possible. As such, the ECOC Day factor appeared to result from local-to-regional scale emissions from around Lake Erie which were transported to Harrow either through down-mixing from the breakdown of the nocturnal boundary layer, or transport across Lake Erie from lake breezes.

The mass spectra of the ECOC Day factor's characteristic particle-types were examined to identify potential source classes. As shown in Fig. 3, all of these particle-types were members of the EC_OC family, each showing a different degree of chemical processing. This strongly implied a carbonaceous source class, although refinement of this identification without the availability of additional mass spectral tracers proved impossible. Hence the geographic origins and particle-type profile for this factor indicated that it was likely emitted by a diversity of local-to-regional carbonaceous sources around Lake Erie.

Unlike the ECOC Day factor, the temporality of the ECOC Night factor (Fig. 2) was not dictated strictly by transport as it only appeared during the night-time when the winds were stagnant $\left(<1 \mathrm{~m} \mathrm{~s}^{-1}\right)$. Furthermore, it appeared to be locally derived as its CPF (Fig. 5e) showed less directionality than the ECOC Day factor, and its PSCF's (not shown) were inconclusive. Consequently, the ECOC Night factor was believed to result either from chemical processing of pre-existing particles or local night-time emissions. As this factor appeared strongly related to the ECOC Day factor due to its sequential appearance during PM episodes and opposing diurnal trend, night-time chemical processing of the pre-existing ECOC Day factor was the more plausible interpretation. This hypothesis was reinforced by similarity in their particle-type profiles, as shown in Fig. 3. On the whole, the ECOC Night particle-types contained significant amounts of nitrate and ammonium, in contrast to the relatively low amounts of these species observed in the dominant particle-types of the daytime factor. This suggested that night-time nitrate uptake may have been the rea- son for their temporal separation. This effect of nitrate partitioning to pre-existing particles has been previously reported by Dall'Osto et al. from the REPARTEE-I field campaign in London (2009). In the aforementioned study, two particle-types showed anti-correlated temporal trends, similar to the ECOC factors reported here: a Long Range Transport (LRT) Nitrate particle-type peaked at night, while a LRT Nitrate core particle-type peaked during the day. During the REPARTEE-I study, the two particle-types were distinguished by nitrate uptake at night, and volatilization during the day, the same effect which led to the two ECOC (Day and Night) factors in this study. In both studies, these particle-types were transported to the site from either localto-regional or regional sources during PM episodes, were mainly carbonaceous in nature, and displayed similar geometric mean sizes (approximately $0.60 \mu \mathrm{m}$ ). In summary, the ECOC Day and Night factors appeared to have originated from carbonaceous emissions from multiple local-toregional sources around Lake Erie, transported to Harrow either through down-mixing during break-up of the nocturnal boundary layer, or lake breezes. The ECOC Night factor appeared to have been separated from the ECOC Day factor by PMF due to night-time chemical processing, namely nitrate uptake.

\subsubsection{Nitrate Background and Nitrate Dust Factors}

The Nitrate Background and Nitrate Dust factors displayed moderate differences in their temporal trends (Fig. 2), yet substantial differences in their particle-type profiles (Fig. 3). Similar to the ECOC Night factor, both contained significant amounts of nitrate, however, unlike the ECOC Day and Night factors, these two nitrate factors were not thought to be related in their source class. Rather, their temporal trends were believed to be the result of chemical processing in the case of Nitrate Background, and a physical process in the case of Nitrate Dust.

Figure 3 shows that particle-types from several families defined the Nitrate Background factor. With contributions from the EC, OC_S_N, OC, and DUST families, and mean particle-type diameters ranging from as low as $0.32 \mu \mathrm{m}$ to $0.64 \mu \mathrm{m}$, this factor was strongly externally mixed (Fig. 3). Although these particle-types were all quite different in composition, each was internally mixed with nitrate and ammonium, as evidenced by mass spectral peaks at $\mathrm{m} / \mathrm{z}-46$ $\left[\mathrm{NO}_{2}^{-}\right],-62\left[\mathrm{NO}_{3}^{-}\right]$, and $+18\left[\mathrm{NH}_{4}^{+}\right]$. Thus, as with the ECOC Night factor, the Nitrate Background factor likely resulted from nitrate uptake to pre-existing particles. However, in this case, these were likely background particles due to their regular appearance over the duration of the campaign, and strong external mixing. Nitrate uptake was first supported by the correlation with $\mathrm{NO}_{2 \text { (g) }}$ (Pearson $r=0.35$, $p<0.05$ ), a particulate nitrate precursor (Seinfeld and Pandis, 2006); this was the highest observed $\mathrm{NO}_{2(\mathrm{~g})}$ correlation among all the PMF factors. Second, the diurnal trend for 
this factor, as shown in Fig. 11, displayed an early morning peak at 05:00, with a subsequent decrease over the next few hours consistent with nitrate evaporation as the temperature rose. A lack of dominant wind directionality, as demonstrated by the CPF (Fig. 5f) and inconclusive results from the PSCF (not shown) reinforced local chemical processing of background particles. Interestingly, particle-type C11 (EC), which mostly resembled particles from source diesel fuel emission studies (Spencer et al., 2006), was mostly apportioned to this factor. This implied that diesel emissions were mostly observed at night at Harrow, contrary to expected daytime local emissions, and local-to-regional scale transport patterns. Yet two physical explanations were possible. It was possible that the shallow, night-time boundary layer enhanced diesel particle concentrations in this semirural region, or that these small particles were only measured by the ATOFMS once they had grown to a detectable size through nitrate coating. Nighttime partitioning of nitrate in locally derived particles has been previously reported during the REPARTEE-I campaign in London (Dall'Osto, et al., 2009). In the aforementioned study, a Local Nitrate particle-type was observed, which contained significant $\mathrm{K}$ and EC, and was designated as locally produced due its small modal diameter $(0.30 \mu \mathrm{m})$. This Local Nitrate particle-type displays some similarities to those from the Nitrate Background factor, mainly in the nitrate uptake to pre-existing locally emitted particles. However, some differences are observed. In this study, particles from the dominant particletype $\mathrm{C} 11$, may not have been strictly locally emitted as the largest source of diesel emissions is located on the localto-regional scale in Windsor. Furthermore, the methodology presented in this study highlighted the strong external mixing in this factor, suggesting that nitrate uptake was nondiscriminatory, partitioning to pre-existing background particles from a range of particle-types from different sourceclasses, both carbonaceous and non-carbonaceous.

In contrast to the Nitrate Background factor, as presented in Fig. 3, the Nitrate Dust factor was less externally mixed: it was composed overwhelmingly of large geometric mean diameter particle-types $(0.96$ to $1.41 \mu \mathrm{m})$ from the DUST family. A high correlation between the Nitrate Dust factor and $\mathrm{PM}_{2.5}$ mass concentration (Pearson $r=0.39, p<0.05$ ) suggested a crustal material contribution. Each dominant particle-type contained significant amounts of nitrate, similar to the Nitrate Background factor. However, this nitrate was believed to be non-volatile as the dominant cations in mass spectra of these particle-types were $\mathrm{Na}^{+}, \mathrm{Ca}^{2+}$, and $\mathrm{K}^{+}$rather than ammonium (i.e. products from the reaction of nitrate with crustal minerals, such as $\mathrm{CaCO}_{3}$ to form $\mathrm{Ca}\left(\mathrm{NO}_{3}\right)_{2}$, Pratt and Prather, 2009). The CPF for this factor, shown in Fig. $5 \mathrm{~g}$, demonstrated an association with the south-westerly direction, which was in line with the directionality of higher wind speeds, and indicated the possibility of wind entrained dust. Its low resolution PSCF (not shown) was highly similar to that of the Long Range Transport factor,

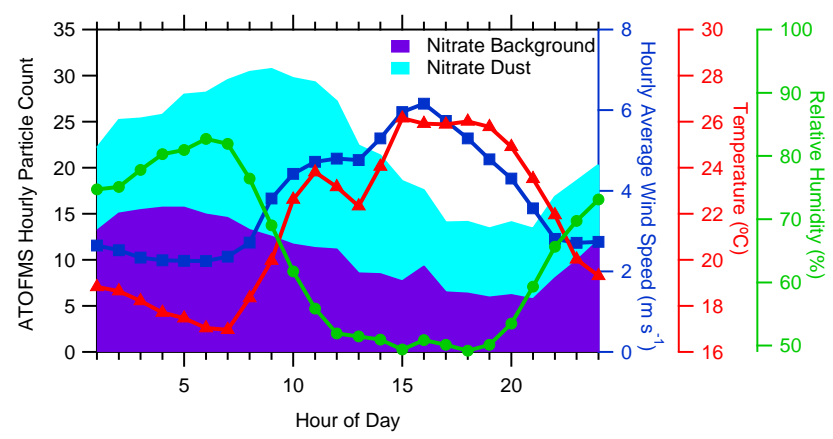

Fig. 11. Stacked diurnal trends for the Nitrate Background and $\mathrm{Ni}$ trate Dust factors along with wind speed, relative humidity and temperature.

indicating possible contributions from distant regions to the south-west. A peak in its diurnal trend at 09:00, simultaneous with the rapid morning rise in wind speed (Fig. 11), was also consistent with local wind liberated dust. However this increase was not sustained throughout the day with increasing wind speeds, and an alternative explanation was sought. Given the abundance of dirt roads and cultivated fields in the region, it is possible that anthropogenic activities, rather than wind, were the major cause for re-suspension of this dust. Accordingly, the decrease in the concentration of these particles after the morning peak could have been due to either decreased anthropogenic activity or greater removal by wind-related atmospheric mixing resulting from breakup of the nocturnal boundary layer.

\section{Atmospheric implications and conclusions}

PMF analysis of ART-2a determined ATOFMS particletypes from the BAQS-Met campaign has resolved nine distinct factors. Through cross-apportionment of particle-types to these factors, the coupled interactions of the atmospheric determinants affecting PM composition in semi-rural southwestern Ontario (the Harrow BAQS-Met supersite) have been elucidated. These determinants were emission source, chemical processing, and transport. This was accomplished via a systematic analysis of the following factor features: the external mixing state of the factors in terms of particletype cross-apportionment; the internal mixing state of those particle-types; and the temporal variability of the factors as related to meteorological conditions.

The determinant that most commonly affected PM composition at Harrow was transport distance and/or time, an observation not surprising given its semi-rural location. Examples of local-to-regional aerosol transport were found in three factors, including carbonaceous emissions from around Lake Erie (ECOC Day factor), fireworks emissions from the Detroit region (Fireworks factor), and predominantly organic emissions from a local-to-regional unknown source to 
the north-west (Organic factor). Regional aerosol transport was distinguished by the Long Range Transport and Biomass Burning factors; the Long Range Transport factor appeared during periods of sustained, synoptic flow from the south and southwest, while the biomass burning factors were in part associated with air masses from the Canadian Prairies. Several locally derived factors were also identified, whose variability was associated with either primary source emissions from mechanical entrainment (Nitrate Dust), or chemical processing (Nitrate Background and ECOC Night).

Information regarding the source classes, as well as the degree of chemical processing, was ascertained by each factor's external mixing of particle-types and those particle-types' internal mixing state. The greatest degree of chemical processing was observed in the Long Range Transport factor, which, logically, showed the weakest external mixing. The significant amount of secondary species that coated these particles likely obscured any distinguishing tracer species, resulting in a more homogeneous aerosol, at least as measured by ATOFMS.

Despite the relatively short duration of this campaign, its distinctive meteorological conditions resulted in the variability in PM composition essential for elucidating stages along the continuum of chemical processing. For instance, the chemical processing of common particle-types was noted for two factor pairs: the Biomass Burning and ECOC factors. In the case of the Biomass Burning factors, a change in particletype chemistry leading to factor separation was attributed to sulphate enrichment. From an analysis of thunderstorm gust front passages, this difference in chemistry was attributable to two possible reasons: either more time for chemical processing, or from one storm having moved just south of Detroit before reaching Harrow, and the other having travelled directly through Detroit's industrialized core. In the case of the ECOC factors, a change in particle-type composition was attributed to nitrate uptake to pre-existing ECOC Day particles. A similar chemical process was observed for background particles in the Nitrate Background factor.

Although this sampling campaign provided the variable meteorological conditions necessary to distinguish stages in chemical processing, resolving this effect using other datasets, while maintaining a mathematically robust solution, requires further study. Hence three recommendations emerge for future PMF analyses of ATOFMS particle-types. First, researchers should ensure that PMF solutions are both mathematically robust and physically meaningful. Second, as for any other receptor modelling study, mathematical diagnostic details of the solution should be reported to provide the receptor modelling community with the opportunity to improve upon this method (Reff et al., 2007; Ulbrich et al., 2009). The last recommendation involves the need for more ATOFMS particle-type receptor modelling studies in tandem with receptor modelling of long-term, lower time-resolution data. It is anticipated that the methodology presented in this study, comprising the systematic examination of inter- nal mixing states and the external mixtures of factor-defining particle-types, can greatly enhance the understanding of factors resolved by low time resolution chemical composition measurements.

\section{Supplementary material related to this article is available online at: http://www.atmos-chem-phys.net/11/8133/2011/ acp-11-8133-2011-supplement.pdf.}

Acknowledgements. These measurements were supported by the Ontario Ministry of Environment and Environment Canada. Funding for SOCAAR was provided by the Canadian Foundation for Innovation, the Ontario Innovation Trust, and the Ontario Research Fund. MLM is grateful to Environment Canada for funding this analysis through the Research Affiliate Program (RAP). The authors gratefully acknowledge the NOAA Air Resources Laboratory (ARL) for the provision of the HYSPLIT transport and dispersion model and/or READY website (http://www.arl.noaa.gov/ready.php) (Draxler and Rolph, 2010; Rolph, 2010), as well as the GOES satellite fire products (http://maps.ngdc.noaa.gov/viewers/firedetects/) used in this publication. The authors wish to thank Q. Li of the Meteorological Service of Canada for producing the highresolution backtrajectories, as well as I. Levy of Environment Canada for providing graphical support. The authors also gratefully acknowledge Agriculture and Agri-Food Canada for providing site infrastructure at Harrow, and Al Melanson from the Ontario Ministry of Environment for his efforts in coordinating site infrastructure and logistics. Comments and suggestions helpful for the improvement of this manuscript from anonymous referees are also gratefully acknowledged.

Edited by: R. McLaren

\section{References}

Aiken, A. C., Salcedo, D., Cubison, M. J., Huffman, J. A., DeCarlo, P. F., Ulbrich, I. M., Docherty, K. S., Sueper, D., Kimmel, J. R., Worsnop, D. R., Trimborn, A., Northway, M., Stone, E. A., Schauer, J. J., Volkamer, R. M., Fortner, E., de Foy, B., Wang, J., Laskin, A., Shutthanandan, V., Zheng, J., Zhang, R., Gaffney, J., Marley, N. A., Paredes-Miranda, G., Arnott, W. P., Molina, L. T., Sosa, G., and Jimenez, J. L.: Mexico City aerosol analysis during MILAGRO using high resolution aerosol mass spectrometry at the urban supersite (T0) - Part 1: Fine particle composition and organic source apportionment, Atmos. Chem. Phys., 9, 66336653, doi:10.5194/acp-9-6633-2009, 2009.

Allen, J. O., Fergenson, D. P., Gard, E. E., Hughes, L. S., Morrical, B. D., Kleeman, M. J., Gross, D. S., Gälli, M. E., Prather, K. A., and Cass, G. R.: Particle detection efficiencies of aerosol time of flight mass spectrometers under ambient sampling conditions, Environ. Sci. Technol., 34, 211-217, 2000.

Ashbaugh, L. L., Malm, W. C., and Sadeh, W. Z.: A residence time probability analysis of sulfur concentrations at Grand-Canyon National Park, Atmos. Environ., 19, 1263-1270, 1985.

Ault, A. P., Gaston, C. J., Wang, Y., Dominguez, G., Thiemens, M. H., and Prather, K. A.: Characterization of the single particle 
mixing state of individual ship plume events measured at the port of Los Angeles, Environ. Sci. Technol., 44, 1954-1961, 2010.

Brook, R. D., Rajagopalan, S., Pope, C. A., Brook, J. R., Bhatnagar, A., Diez-Roux, A. V., Holguin, F., Hong, Y., Luepker, R. V., Mittleman, M. A., Peters, A., Siscovick, D., Smith, S. C., Whitsel, L., and Kaufman, J. D.: Particulate matter air pollution and cardiovascular disease: An update to the scientific statement from the American Heart Association, Circulation, 121, 2331-2378, 2010.

Buset, K. C., Evans, G. J., Leaitch, W. R., Brook, J. R., and ToomSauntry, D.: Use of advanced receptor modelling for analysis of an intensive 5-week aerosol sampling campaign, Atmos. Environ., 40, S482-S499, 2006.

Carpenter, G. A., Grossberg, S., and Rosen, D. B.: Art 2-a: An adaptive resonance algorithm for rapid category learning and recognition, Neural Networks, 4(4), 493-504, 1991.

Cote, J., Gravel, S., Methot, A., Patoine, A., Roch, M., and Staniforth, A.: The operational CMC-MRB global environmental multiscale (GEM) model. Part I: Design considerations and formulation, Mon. Weather Rev., 126, 1373-1395, 1998.

D'Amours, R.: Modeling the ETEX plume dispersion with the Canadian emergency response model, Atmos. Environ., 32, 4335-4341, 1998.

Dall'Osto, M. and Harrison, R. M.: Chemical characterisation of single airborne particles in Athens (Greece) by ATOFMS, Atmos. Environ., 40, 7614-7631, 2006.

Dall'Osto, M., Harrison, R. M., Coe, H., Williams, P. I., and Allan, J. D.: Real time chemical characterization of local and regional nitrate aerosols, Atmos. Chem. Phys., 9, 3709-3720, doi:10.5194/acp-9-3709-2009, 2009.

Dockery, D. W., Pope, C. A., Xu, X. P., Spengler, J. D., Ware, J. H., Fay, M. E., Ferris, B. G., and Speizer, F. E.: An association between air-pollution and mortality in six U.S. cities, New England Journal of Medicine, 329, 1753-1759, 1993.

Draxler, R. R.: Description of the HYSPLIT4 modeling system, NOAA technical memorandum ARL-224, edited by: NOAA, Air Resources Laboratory, Silver Springs, MD, 1997.

Draxler, R. R. and Rolph, G. D.: HYSPLIT (Hybrid Single-Particle Lagrangian Integrated Trajectory) Model access via NOAA ARL READY, available at: http://ready.arl.noaa.gov/hysplit.php (last access: December 2010), NOAA Air Resources Laboratory, Silver Spring, MD, 2011.

Drewnick, F., Hings, S. S., Curtius, J., Eerdekens, G., and Williams, J.: Measurement of fine particulate and gas-phase species during the New Year's fireworks 2005 in Mainz, Germany, Atmos. Environ., 40, 4316-4327, 2006.

Drewnick, F., Dall'Osto, M., and Harrison, R.: Characterization of aerosol particles from grass mowing by joint deployment of ToFAMS and ATOFMS instruments, Atmos. Environ., 42, 30063017, 2008.

Eatough, D. J., Grover, B. D., Woolwine, W. R., Eatough, N. L., Prather, K. A., Shields, L., Qin, X., Denkenberger, K., Long, R., and Farber, R.: Source apportionment of $1 \mathrm{~h}$ semi-continuous data during the 2005 Study of Organic Aerosols in Riverside (SOAR) using positive matrix factorization, Atmos. Environ., 42, 2706-2719, 2008.

Gard, E., Mayer, J. E., Morrical, B. D., Dienes, T., Fergenson, D. P., and Prather, K. A.: Real-time analysis of individual atmospheric aerosol particles: Design and performance of a portable atofms,
Anal. Chem., 69, 4083-4091, doi:10.1021/ac970540n, 1997.

Gong, W., Dastoor, A. P. , Bouchet, V. S. , Gong, S. , Makar, P. A., Moran, M. D., Pabla, B., M'enard, S., Crevier, L.-P., Cousineau, S., and Venkatesh, S.: Cloud processing of gases and aerosols in a regional air quality model (AURAMS), Atmos. Res., 82, 248275, 2006.

Healy, R. M., Hellebust, S., Kourtchev, I., Allanic, A., O’Connor, I. P., Bell, J. M., Healy, D. A., Sodeau, J. R., and Wenger, J. C.: Source apportionment of $\mathrm{PM}_{2.5}$ in Cork Harbour, Ireland using a combination of single particle mass spectrometry and quantitative semi-continuous measurements, Atmos. Chem. Phys., 10, 9593-9613, doi:10.5194/acp-10-9593-2010, 2010.

IPCC: Climate Change 2007 - The Physical Science Basis. Working Group I Contribution to the Fourth Assessment Report of the IPCC, Cambridge University Press, Cambridge, UK, 2007.

Jeong, C.-H., McGuire, M. L., Godri, K. J., Slowik, J. G., Rehbein, P. J. G., and Evans, G. J.: Quantification of aerosol chemical composition using continuous single particle measurements, Atmos. Chem. Phys., 11, 7027-7044, doi:10.5194/acp-11-70272011, 2011a.

Jeong, C.-H., McGuire, M. L., Herod, D., Dann, T., DabekZlotorzynska, E., Wang, D., Ding, L., Celo, V., Mathieu, D., and Evans, G. J.: Receptor modeling based identification of the sources of $\mathrm{PM}_{2.5}$ in Canadian cities, Atmos. Pollution Res., 2, 158-171, doi:10.5094/APR.2011.021, 2011 b.

Joly, A., Smargiassi, A., Kosatsky, T., Fournier, M., DabekZlotorzynska, E., Celo, V., Mathieu, D., Servranckx, R., D'Amours, R., Malo, A., and Brooks, J.: Characterisation of particulate exposure during fireworks displays, Atmos. Environ., 44, 4325-4329, 2010.

Kim, E., Larson, T. V., Hopke, P. K., Slaughter, C., Sheppard, L. E., and Claiborn, C.: Source identification of $\mathrm{PM}_{2.5}$ in an arid Northwest U.S. city by positive matrix factorization, Atmos. Res., 66, 291-305, 2003.

Lanz, V. A., Alfarra, M. R., Baltensperger, U., Buchmann, B., Hueglin, C., and Prvt, A. S. H.: Source apportionment of submicron organic aerosols at an urban site by factor analytical modelling of aerosol mass spectra, Atmos. Chem. Phys., 7, 15031522, doi:10.5194/acp-7-1503-2007, 2007.

Lewis, C. W., Norris, G. A., Conner, T. L., and Henry, R. C.: Source apportionment of Phoenix PM2.5 aerosol with the UNMIX receptor model, J. Air Waste Manage. Assoc., 53, 325-338, 2003.

Liu, D. Y., Rutherford, D., Kinsey, M., and Prather, K. A.: Real-time monitoring of pyrotechnically derived aerosol particles in the troposphere, Anal. Chem., 69, 1808-1814, doi:10.1021/ac9612988, 1997.

Liu, D. Y., Wenzel, R. J., and Prather, K. A.: Aerosol time-offlight mass spectrometry during the Atlanta supersite experiment: 1. Measurements, J. Geophys. Res.-Atmos., 108, 8426, doi:10.1029/2001jd001562, 2003.

Lloyd, S. P.: Least-squares quantization in PCM, IEEE Transactions on Information Theory, 28, 129-137, 1982.

MacQueen, J.: Some methods for the classification and analysis of multivariate observations, Fifth Berkeley Symposium on Mathematical Statistics and Probability, Berkeley, 1967.

Makar, P. A., Gong, W., Mooney, C., Zhang, J., Davignon, D., Samaali, M., Moran, M. D., He, H., Tarasick, D. W., Sills, D., and Chen, J.: Dynamic adjustment of climatological ozone boundary conditions for air-quality forecasts, Atmos. Chem. 
Phys., 10, 8997-9015, doi:10.5194/acp-10-8997-2010, 2010.

Moreno, T., Querol, X., Alastuey, A., Cruz Minguillon, M., Pey, J., Rodriguez, S., Vicente Miro, J., Felis, C., and Gibbons, W.: Recreational atmospheric pollution episodes: Inhalable metalliferous particles from firework displays, Atmos. Environ., 41, 913-922, 2007.

Nel, A.: Air pollution-related illness: Effects of particles, Science, 308, 804-806, 2005.

Noble, C. A., Nordmeyer, T., Salt, K., Morrical, B., and Prather, K. A.: Aerosol characterization using mass spectrometry, Trends Anal. Chem., 13(5), 218-222, 1994.

Norris, G., Vedantham, R., Wade, K., Brown, S., Prouty, J., and Foley, C.: EPA positive matrix factorization (PMF) 3.0 fundamentals \& user guide, EPA, 2008.

OME: Ontario Ministry of the Environment - Air Quality in Ontario report, 2008.

Owega, S., Khan, B. U. Z., D’Souza, R., Evans, G. J., Fila, M., and Jervis, R. E.: Receptor modeling of Toronto PM2.5 characterized by aerosol laser ablation mass spectrometry, Environ. Sci. Tech., 38, 5712-5720, 2004.

Paatero, P.: Least squares formulation of robust non-negative factor analysis, Chemometr. Intell. Lab., 37, 23-35, 1997.

Paatero, P.: User's guide for postitive matrix factorization programs for PMF2.EXE and PMF3.EXE, University of Helsinki, Finland, 2007.

Paatero, P. and Hopke, P. K.: Discarding or downweighting highnoise variables in factor analytic models, Anal. Chim. Acta, 490, 277-289, doi:10/1016/s0003-2670(02)01643-4, 2003.

Paatero, P. and Tapper, U.: Analysis of different modes of factoranalysis as least-squares fit problems, Chemometr. Intell. Lab., 18, 183-194, 1993.

Paatero, P. and Tapper, U.: Positive matrix factorization - a nonnegative factor model with optimal utilization of error estimates of data values, Environmetrics, 5, 111-126, 1994.

Pope, C. A. and Dockery, D. W.: Health effects of fine particulate air pollution: Lines that connect, J. Air Waste Manage., 56, 709742, 2006

Prather, K. A., Nordmeyer, T., and Salt, K.: Real-time characterization of individual aerosol particles using time-of-flight mass spectrometry, Anal. Chem., 66, 1403-1407, 1994.

Pratt, K. A. and Prather, K. A.: Real-time, single-particle volatility, size, and chemical composition measurements of aged urban aerosols, Environ. Sci. Technol., 43, 8276-8282, 2009.

Qin, X. and Prather, K. A.: Impact of biomass emissions on particle chemistry during the California regional particulate air quality study, Int. J. Mass Spectrom., 258, 142-150, 2006.

Reff, A., Eberly, S. I., and Bhave, P. V.: Receptor modeling of ambient particulate matter data using positive matrix factorization: Review of existing methods, J. Air Waste Manage., 57, 146-154, 2007.

Rehbein, P. J. G., Jeong, C.-H., McGuire, M. L., Yao, X., Corbin, J., and Evans, G. J.: Cloud and fog processing enhanced gas-toparticle partitioning of trimethylamine, Environ. Sci. Technol., 45, 4346-4352, 2011.

Reilly, P. T. A., Lazar, A. C., Gieray, R. A., Whitten, W. B., and Ramsey, J. M.: The elucidation of charge-transfer-induced matrix effects in environmental aerosols via real-time aerosol mass spectral analysis of individual airborne particles, Aerosol Sci. Tech., 33, 135-152, 2000.
Rolph, G. D.: Real-time Environmental Applications and Display sYstem (READY) Website (http://ready.arl.noaa.gov), NOAA Air Resources Laboratory, Silver Spring, MD, 2011.

Seinfeld, J. H. and Pandis, S. N.: Atmospheric chemistry and physics : From air pollution to climate change, 2nd ed., Wiley, Hoboken, NJ, xxviii, 1203 pp., 2006.

Sills, D. M. L., Brook, J. R., Levy, I., Makar, P. A., Zhang, J., and Taylor, P. A.: Lake breezes in the southern Great Lakes region and their influence during BAQS-Met 2007, Atmos. Chem. Phys. Discuss., 11, 3579-3626, doi:10.5194/acpd11-3579-2011, 2011.

Silva, P. J. and Prather, K. A.: On-line characterization of individual particles from automobile emissions, Environ. Sci. Technol., 31, 3074-3080, 1997.

Silva, P. J. and Prather, K. A.: Interpretation of mass spectra from organic compounds in aerosol time-of-flight mass spectrometry, Anal. Chem., 72, 3553-3562, 2000.

Silva, P. J., Liu, D. Y., Noble, C. A., and Prather, K. A.: Size and chemical characterization of individual particles resulting from biomass burning of local southern California species, Environ. Sci. Technol., 33, 3068-3076, 1999.

Slowik, J. G., Vlasenko, A., McGuire, M., Evans, G. J., and Abbatt, J. P. D.: Simultaneous factor analysis of organic particle and gas mass spectra: AMS and PTR-MS measurements at an urban site, Atmos. Chem. Phys., 10, 1969-1988, doi:10.5194/acp-10-19692010, 2010.

Slowik, J. G., Brook, J., Chang, R. Y.-W., Evans, G. J., Hayden, K., Jeong, C.-H., Li, S.-M., Liggio, J., Liu, P. S. K., McGuire, M., Mihele, C., Sjostedt, S., Vlasenko, A., and Abbatt, J. P. D.: Photochemical processing of organic aerosol at nearby continental sites: contrast between urban plumes and regional aerosol, Atmos. Chem. Phys., 11, 2991-3006, doi:10.5194/acp-11-29912011, 2011.

Song, X. H., Hopke, P. K., Fergenson, D. P., and Prather, K. A.: Classification of single particles analyzed by ATOFMS using an artificial neural network, ART-2a, Anal. Chem., 71, 860-865, 1999.

Spencer, M. T., Shields, L. G., Sodeman, D. A., Toner, S. M., and Prather, K. A.: Comparison of oil and fuel particle chemical signatures with particle emissions from heavy and light duty vehicles, Atmos. Environ., 40, 5224-5235, 2006.

Sullivan, R. C., Guazzotti, S. A., Sodeman, D. A., and Prather, K. A.: Direct observations of the atmospheric processing of Asian mineral dust, Atmos. Chem. Phys., 7, 1213-1236, doi:10.5194/acp-7-1213-2007, 2007.

Ulbrich, I. M., Canagaratna, M. R., Zhang, Q., Worsnop, D. R., and Jimenez, J. L.: Interpretation of organic components from Positive Matrix Factorization of aerosol mass spectrometric data, Atmos. Chem. Phys., 9, 2891-2918, doi:10.5194/acp-9-2891-2009, 2009.

Vecchi, R., Bernardoni, V., Cricchio, D., D’Alessandro, A., Fermo, P., Lucarelli, F., Nava, S., Piazzalunga, A., and Valli, G.: The impact of fireworks on airborne particles, Atmos. Environ., 42, 1121-1132, 2008

Watson, J. G.: Visibility: Science and regulation, J. Air Waste Manage., 52, 628-713, 2002.

Wenzel, R. J., Liu, D. Y., Edgerton, E. S., and Prather, K. A.: Aerosol time-of-flight mass spectrometry during the Atlanta supersite experiment: 2. Scaling procedures, J. Geophys. Res.- 
Atmos., 108, 8427, doi:10.1029/2001jd001563, 2003.

Wexler, A. S. and Johnston, M. V.: What have we learned from highly time-resolved measurements during EPA's supersites program and related studies?, J. Air Waste Manage., 58, 303-319, 2008.

Whiteaker, J. R. and Prather, K. A.: Hydroxymethanesulfonate as a tracer for fog processing of individual aerosol particles, Atmos. Environ., 37, 1033-1043, 2003.

Williams, B., Goldstein, A., Kreisberg, N., and Hering, S.: An in-situ instrument for speciated organic composition of atmospheric aerosols: Thermal desorption aerosol GC/MS-FID (TAG), Aerosol Sci. Technol., 40, 627-638, 2006.
Williams, B. J., Goldstein, A. H., Kreisberg, N. M., Hering, S. V., Worsnop, D. R., Ulbrich, I. M., Docherty, K. S., and Jimenez, J. L.: Major components of atmospheric organic aerosol in southern California as determined by hourly measurements of source marker compounds, Atmos. Chem. Phys., 10, 11577-11603, doi:10.5194/acp-10-11577-2010, 2010.

Zhang, Q., Alfarra, M. R., Worsnop, D. R., Allan, J. D., Coe, H., Canagaratna, M. R., and Jimenez, J. L.: Deconvolution and quantification of hydrocarbon-like and oxygenated organic aerosols based on aerosol mass spectrometry, Environ. Sci. Technol., 39, 4938-4952, 2005. 